\title{
Plant-Derived Anticancer Compounds as New Perspectives in Drug Discovery and Alternative Therapy
}

\author{
Cristina Adriana Dehelean ${ }^{1,2, \dagger}$, Iasmina Marcovici ${ }^{1,2,+}$, Codruta Soica ${ }^{1,2, *}$, Marius Mioc ${ }^{1,2, *}$,

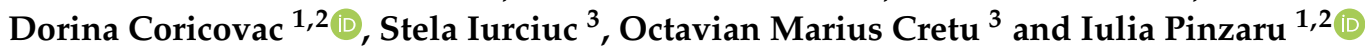 \\ 1 Research Center for Pharmaco-Toxicological Evaluations, Faculty of Pharmacy, "Victor Babes" University of \\ Medicine and Pharmacy Timisoara, Eftimie Murgu Square No. 2, RO-300041 Timisoara, Romania; \\ cadehelean@umft.ro (C.A.D.); iasmina.marcovici@umft.ro (I.M.); dorinacoricovac@umft.ro (D.C.); \\ iuliapinzaru@umft.ro (I.P.) \\ 2 Faculty of Pharmacy, "Victor Babeș" University of Medicine and Pharmacy Timisoara, Eftimie Murgu Square \\ No. 2, RO-300041 Timisoara, Romania \\ 3 "Victor Babeș" University of Medicine and Pharmacy Timisoara, Faculty of Medicine, Eftimie Murgu Square \\ No. 2, RO-300041 Timisoara, Romania; siurciuc@umft.ro (S.I.); tavi@octaviancretu.ro (O.M.C.) \\ * Correspondence: codrutasoica@umft.ro (C.S.); marius.mioc@umft.ro (M.M.) \\ + These authors contributed equally to this work.
}

Citation: Dehelean, C.A.; Marcovici, I.; Soica, C.; Mioc, M.; Coricovac, D.; Iurciuc, S.; Cretu, O.M.; Pinzaru, I. Plant-Derived Anticancer Compounds as New Perspectives in Drug Discovery and Alternative Therapy. Molecules 2021, 26, 1109. https://doi.org/10.3390/ molecules26041109

Academic Editor: Gianni Sacchetti Received: 1 February 2021

Accepted: 16 February 2021

Published: 19 February 2021

Publisher's Note: MDPI stays neutral with regard to jurisdictional claims in published maps and institutional affiliations.

Copyright: (c) 2021 by the authors. Licensee MDPI, Basel, Switzerland. This article is an open access article distributed under the terms and conditions of the Creative Commons Attribution (CC BY) license (https:// creativecommons.org/licenses/by/ $4.0 /)$.

\begin{abstract}
Despite the recent advances in the field of chemically synthetized pharmaceutical agents, nature remains the main supplier of bioactive molecules. The research of natural products is a valuable approach for the discovery and development of novel biologically active compounds possessing unique structures and mechanisms of action. Although their use belongs to the traditional treatment regimes, plant-derived compounds still cover a large portion of the current-day pharmaceutical agents. Their medical importance is well recognized in the field of oncology, especially as an alternative to the limitations of conventional chemotherapy (severe side effects and inefficacy due to the occurrence of multi-drug resistance). This review offers a comprehensive perspective of the first blockbuster chemotherapeutic agents of natural origin's (e.g. taxol, vincristine, doxorubicin) mechanism of action using 3D representation. In addition is portrayed the step-by-step evolution from preclinical to clinical evaluation of the most recently studied natural compounds with potent antitumor activity (e.g. resveratrol, curcumin, betulinic acid, etc.) in terms of anticancer mechanisms of action and the possible indications as chemotherapeutic or chemopreventive agents and sensitizers. Finally, this review describes several efficient platforms for the encapsulation and targeted delivery of natural compounds in cancer treatment
\end{abstract}

Keywords: bioactive compounds; doxorubicin, paclitaxel, vincristine, resveratrol, curcumin, rutin, betulinic acid, antitumoral effect; chemoprevention

\section{Introduction}

Nature stands as an infinite and inexhaustible resource for the development of novel effective drugs, chemotypes and pharmacophores [1]. Medicinal herbs have a wide outspread globally and, in recent years, have become of essential importance in treating diseases. Their therapeutic role is provided by bioactive molecules, the components of the plant's chemical core [2]. Since ancient times, natural compounds have played an important role in the treatment and prevention of various pathologies, forming the backbone of the traditional system of healing [3,4]. Furthermore, terrestrial plants (e.g. Artemisia annua L., Camptotheca acuminata Decne., Gingko biloba L., Curcuma longa L., Podophyllum peltatum L., Taxus brevifolia, Taxus baccata, Combretum caffrum, Euphorbia peplus, etc.) still dominate in current-day therapeutic approaches, since the plant-derived compounds comprise a large portion of current pharmaceutical agents, most notably in the areas of antibiotherapy and chemotherapy [4]. 
The role of natural compounds as drugs or as a basis for the development of new drugs is thoroughly explained in the most recent review published by Newman and Cragg [5]. According to their data, out of a total of 1881 new approved drugs (antibacterial, antifungal, antiviral, antiparasitic, antitumor, etc.) in the last four decades, 929 have natural origin and fall into the class of biological macromolecules, unaltered natural products, botanical drugs, or derivatives of natural products or vaccines, while the other 952 drugs are classified as synthetic drugs, synthetic drugs with natural product pharmacophores or as drugs that mimic a natural product [5].

The use of herbal medicines has been widely embraced as a complementary or alternative option in the oncology field (Catharanthus roseus, Podophyllum peltatum L., Taxus brevifolia Nutt., Taxus baccata, etc.) [3,4]. Therefore, every year, several novel cytotoxic compounds are isolated from plants and constitute new possibilities to fight cancer. Many researchers center their attention on the investigation of naturally occurring molecular entities that might become useful to the pharmaceutical industry [6]. Those who discover compounds exerting antitumor activity during preclinical studies seek out for clinical efficacy confirmation too.

Carcinogenesis, the phenomenon of cancer arising and developing, is a step-by-step process [7] characterized by the progression of distinct molecular changes [8], accumulation of mutations and epigenetic alterations that activate oncogenes, inactivation of tumor suppressor genes, hindrance of DNA repair machinery and disruption of apoptosis mechanisms [7], which compels cells to undergo uncontrolled cellular division [8]. A single alteration is not able to promote tumorigenesis, but a collection of multiple modifications that affect cellular homeostasis is necessary to make cells lose control of proliferation [7]. With each disturbance, cells undergo fundamental changes, leading to tumor initiation, promotion and progression [8]. Tumor initiation is a rapid and irreversible process that begins with the exposure to a carcinogenic agent, followed by its transportation to tissues where it causes DNA mutations. During the promotion stage, which is a long and reversible process, the tumor-initiated cells proliferate, allowing the accumulation of additional mutations. The final stage of neoplastic transformation, progression, occurs after these mutations generate an invasive and metastatic cellular phenotype [8]. Regarding cancer therapy, definitive tumor eradication through surgical resection, radiation therapy, immunotherapy and chemotherapy continues to be part of the current mainstay treatment regimens [4,9]. However, the prevention of carcinogenesis is highly preferable to treatment [4], as cancer is largely a preventable disease that can be attributed to lifestyle factors (such as smoking and nutritional status) [10]. The concept of chemoprevention is gaining more public attention especially because it is cost-effective and avoids the toxic side effects following cancer treatment [10].

The benefits of natural compounds as reduced adverse effects and the capacity to impact on multiple signaling pathways involved in the carcinogenesis process could be considered an explanation for the fact that from 240 antitumor drugs approved in the last 40 years, only 29 are strictly synthetic drugs. Moreover, in the past 10 years, synthetic compounds with pharmacophore of natural origin that mimic the natural product effect were approved as antitumor drugs [5].

Phytochemicals have been in the spotlight of cancer research since its early beginnings, as they were among the first antineoplastic drugs discovered (e.g., leucovorin in 1950, carzinophilin in 1954, vincristine in 1963, actinomycin D in 1964, etc.) [5]. Furthermore, their study continued to the present day. It is of great importance to mention that natural compounds not only serve as chemotherapeutic agents, but also as adjuvants in cancer treatment.

This review offers a new perspective regarding the role of natural compounds in the oncology field by summarizing the three directions of their anticancer activity: (I) chemotherapeutic agents due to their innate antitumor effect; (II) chemopreventive agents; (III) sensitizers in multi-drug resistance. 


\section{Natural Compounds Recognized as Chemotherapeutic Agents \\ 2.1. Natural Compounds Approved as Chemotherapeutic Agents}

Terrestrial plants, microbes, slime molds and the marine environment represent important sources of novel pharmacologically active molecules, providing a library of promising therapeutic agents [4]. Many blockbuster drugs are directly or indirectly derived from natural products and were or still are in clinical use $[1,11,12]$. Despite the increased popularity of the synthetic products which led to many drugs existing nowadays [1], the secondary metabolites from plants remain vital for drug design [2], as their core structures serve as templates for the synthesis or semi-synthesis of novel substances for the treatment of diseases affecting humankind [1]. Additionally, while the safety-efficacy report of synthetic drugs remains debatable, the naturally occurring molecules still play a dominant role in the treatment of human ailments $[1,4,13]$ due to their high patient tolerance and acceptance [1]. Conventional chemotherapy drugs (e.g., methotrexate, cisplatin) are associated with severe adverse reactions such as hair loss, gastrointestinal lesion, bone marrow sup-pression, neurologic dysfunction, and drug resistance, while phytocompounds proved to be less toxic and more effective $[2,14,15]$. Presently, the molecules that occur in nature comprise a large portion of the current-day pharmaceutical agents, most notably in the area of antibiotics and cancer drugs [4], among which 60 to $80 \%$ are derived from natural products [16]. Moreover, about one third of the world's best-selling drugs are natural compounds or their derivatives [16]. The most representative example is the legendary discovery of the first antibiotic penicillin from the fungus Penicillium notatum, by Alexander Fleming, who noticed that "around a large colony of a contaminating mold the staphylococcus colonies became transparent and were obviously undergoing lysis" [2,17]. Antibiotics stood out even in the field of cancer treatment, being among the most important of the chemotherapeutic agents. These include members of the actinomycin, ansamycin, anthracycline, bleomycin, epothilone and staurosporine classes [4]. Anthracycline chemotherapy regimens play a central role in the treatment of many cancer types including breast cancer and lymphoma. Doxorubicin (derived from microbes), its precursor daunorubicin, epirubicin and idarubicin (Figure 1) are the most common four anthracyclines, among which the first two are the earliest anthracyclines to be put into clinical practice [18]. Their cytotoxic effects are a result of several mechanistic approaches, including topoisomerase II, DNA and RNA inhibitions. Topoisomerase II decreases DNA supercoiling by cutting DNA double strands during replication. Anthracyclines bind DNA and topoisomerase II isoenzymes, forming a ternary complex that causes double-stranded DNA breaks. Topoisomerase II $\alpha$ (TopII $\alpha$ ) is the most prevalent isoenzyme, being highly expressed in malignant cells [18]. When bound to TopII $\alpha$, anthracyclines block its catalytic activity, stabilize DNA breaks and inhibit DNA replication [18]. Moreover, anthracyclines intercalate with DNA bases by forming adducts and inhibit the activity of DNA and RNA polymerases that result in the blockage of DNA and RNA synthesis. The interactions of anthracyclines with nucleic acids, especially DNA, are very well documented starting from the 1990s. The extensive research conducted allowed the observation of binding patterns and base pair interaction behavior between DNA strands and anthracyclines by obtaining 3D crystallographic structures of DNA-anthracycline complexes [19]. These structures show how anthracyclines are strongly bound to DNA base pairs through multiple hydrogen bonds (Figure 2) and outline the mobility changes in base pairs when interacting with these molecules. Nevertheless, despite the great results recorded in tumor regression, anthracycline therapy may result in a high cardiac risk [20]. Bleomycin (Figure 1) belongs to the family of glycopeptide antibiotics and is primarily indicated as an antineoplastic agent. Its mechanism of action involves the oxidative damage of DNA via metal ions binding, which results in the formation of metallobleomycin complexes. Moreover, chromosomal aberrations, chromatid breaks and translocations were observed after the exposure to this antibiotic. Bleomycin received the FDA-approval for the treatment of various malignancies such as squamous cell carcinomas, testicular cancers, Hodgkin and non-Hodgkin lymphomas [21]. 


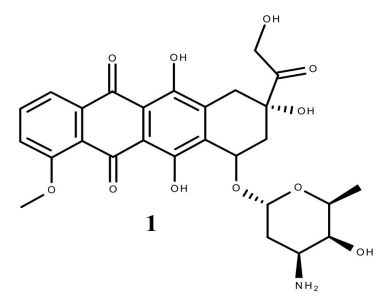

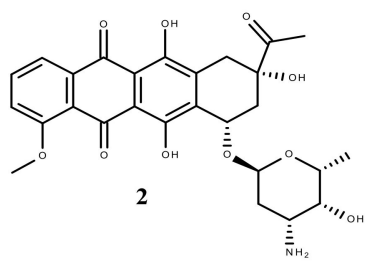

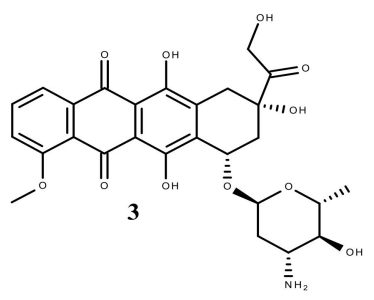<smiles>CC(=O)[C@]1(C)Cc2c(C)c3c(c(C)c2[C@@H](C[C@@H]2C[C@H](C)[C@@H](C)[C@H](C)O2)C1)C(=O)c1ccccc1C3=O</smiles>

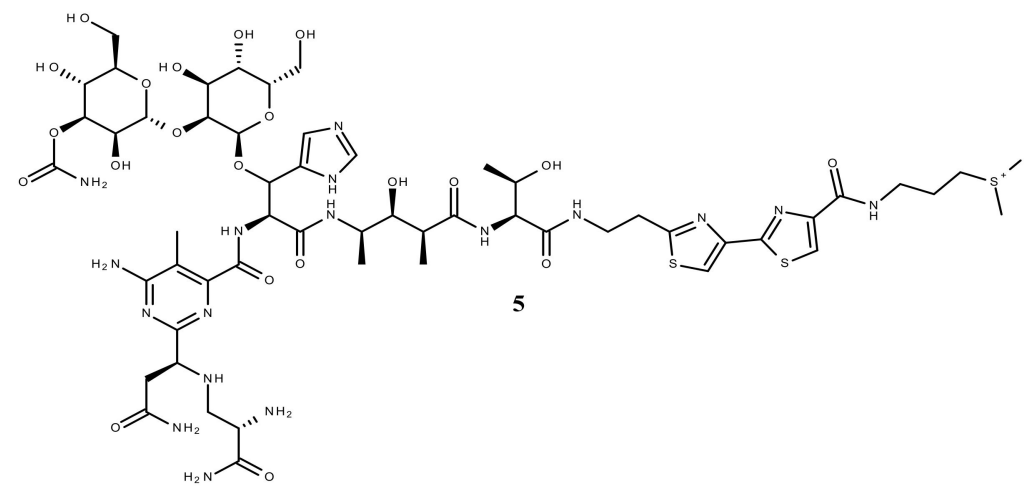

Figure 1. Chemical structures of (1) doxorubicin, (2) daunorubicin, (3) epirubicin, (4) idarubicin and (5) bleomycin.

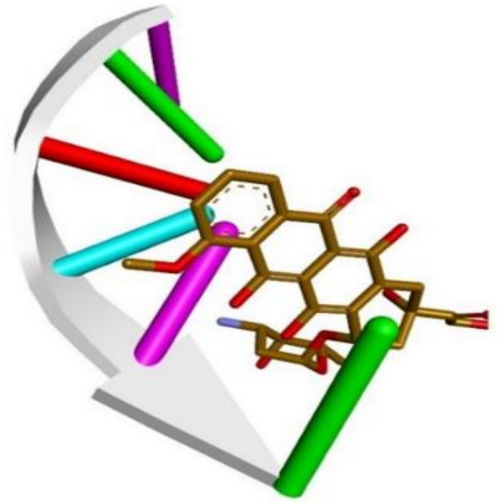

(a)

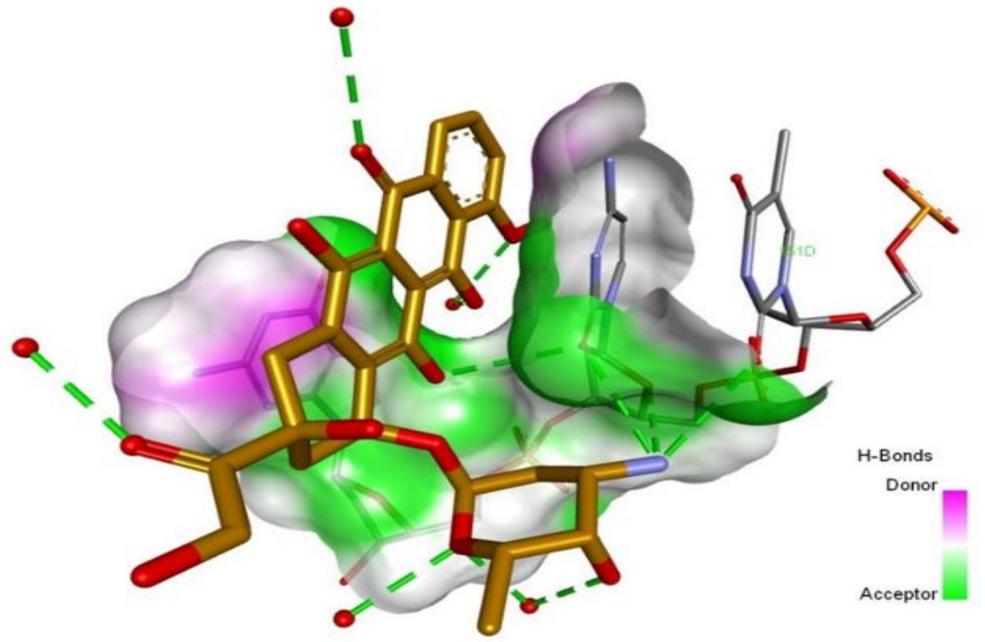

(b)

Figure 2. (a) Crystallographic 3D structure of doxorubicin (gold) in complex with DNA (PDB ID: 151D), d(CGATCG) and (b) the anthracycline structure is strongly bound to DNA base pairs through multiple hydrogen bonds (HBs) depicted as green dotted lines; DNA-ligand representation was achieved using Biovia Discovery Studio 4.1 (Dassault Systems).

Taxus species are a veritable source of taxanes which became one of the most important classes of chemotherapeutic drugs in the modern clinical use [4]. However, they have a long history of use in folk medicine against breast and ovarian cancers [20]. There are two relevant drugs belonging to this class of natural anticancer agents-paclitaxel, originally isolated from the bark of Taxus brevifolia, and docetaxel, the semisynthetic analogue of a compound abundant in the leaves of Taxus baccata (Figure 3a). Even though compounds such as docetaxel and cabazitaxel are taxoid semisynthetic derivatives, important structural modulations occur at the NH group as compared to paclitaxel. Other structural differences are related to the degree of methylation or acetylation of the outer ring $\mathrm{OH}$ groups. Microtubules are $\alpha, \beta$-tubulin containing components that assemble longitudinally into protofilaments also playing a key role in cell division [22]. The antitumoral effect of taxanes 
is based on their ability to promote the polymerization of tubulin heterodimers to stabilize microtubules (Figure $3 \mathrm{~b}$ ) and suppress the dynamic changes in microtubules, leading to mitotic arrest. Taxanes stabilize microtubules by binding to the $\beta$-tubulin subunit. The strong microtubule stabilization effect relies upon the multiple HB that the taxane compound forms within the $\beta$-tubulin binding site (Figure 3c) [22]. Therefore, the derivatization of $\mathrm{OH}$ groups in obtaining semisynthetic derivatives is limited to alkylation/acylation, because of the important role that these functional groups play in HB formation. Currently, both paclitaxel and docetaxel are highly recommended in the treatment of breast and non-small cell lung malignancies. Additionally, paclitaxel has also shown efficacy against Kaposi's sarcoma and ovarian cancer [4]. Their high value in chemotherapy, as well as clinical limitations including solubility issues and toxicity, led to the development of taxoid-analogues which are currently in different stages of clinical trials [4]. For instance, cabazitaxel, which conserves the same mechanism of action [20], proved to be active against several types of malignant neoplasms, including prostate, bladder, brain, ovarian, stomach and urinary tract cancers [4].

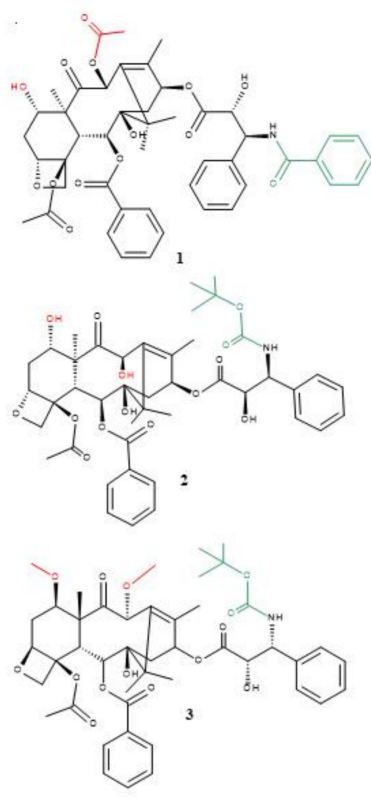

(a)

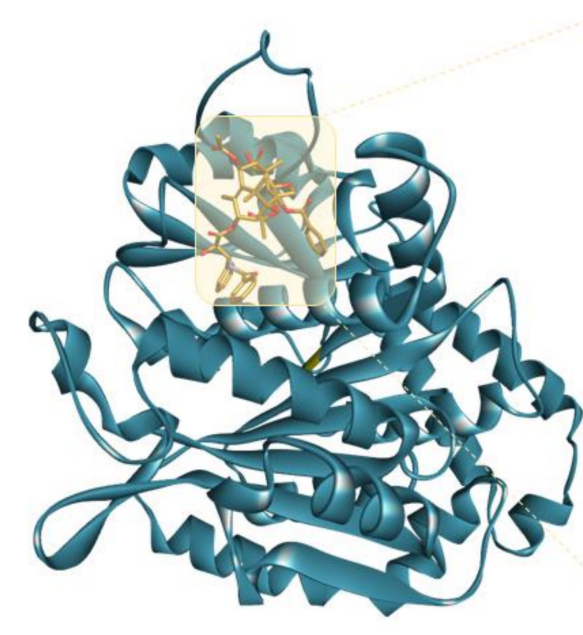

(b)

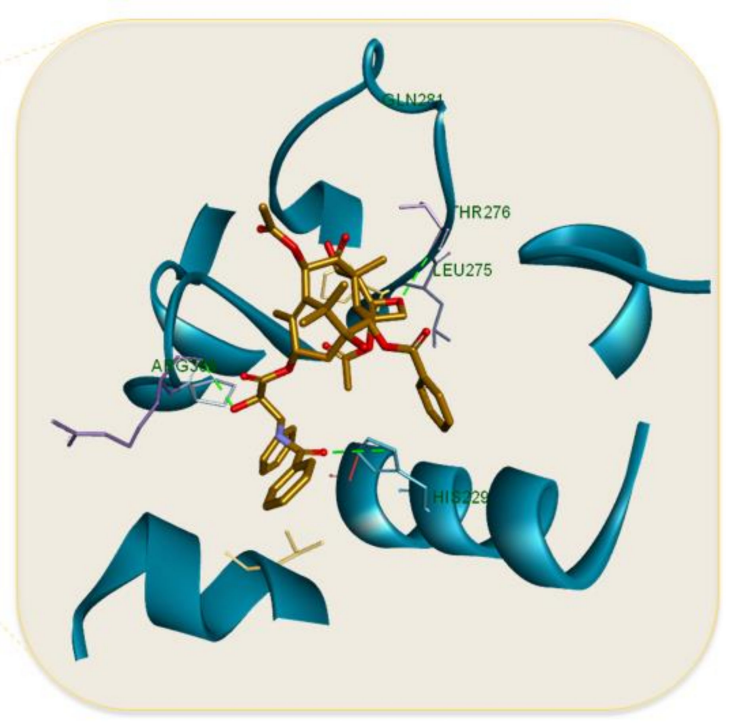

(c)

Figure 3. (a) Chemical structures of (1) paclitaxel, (2) docetaxel, and (3) cabazitaxel, major structural differences are highlighted in green while alkylation/acylation of $\mathrm{OH}$ groups is highlighted in red; (b) 3D structure of stabilized microtubule chain A (blue) (PDB ID: 5SYF) in complex with taxol (gold) and (c) important HBs (green dotted lines) formed by the taxane structure within the $\beta$-tubulin binding site. Protein-ligand representation was achieved using Biovia Discovery Studio 4.1 (Dassault Systems).

The Vinca alkaloids, vincristine and vinblastine (Figure 4), are the first plant-derived anticancer drugs to enter the clinical use [23]. Originally isolated from the Madagascar periwinkle, Catharanthus roseus, they show great antiproliferative activity by disrupting microtubules, causing cell arrest in the metaphase and leading to apoptotic cellular death [4]. They were used as templates for the development of effective semisynthetic derivatives, including vindesine, vinorelbine and its bifluorinated analogue, vinflunine (Figure 4) [4]. Podophyllotoxin, the active constituent of Podophyllum peltatum L. which is carrying a long tradition of use in the treatment of skin cancer and warts, contributed to the semisynthesis of two clinically effective derivatives - etoposide and teniposide (Figure 4). Their mechanism of action, in contradiction to podophyllotoxin, which reversibly binds to tubulin [4], consists of the inhibition of the DNA synthesis, breakdown of the DNA stand and stabi- 


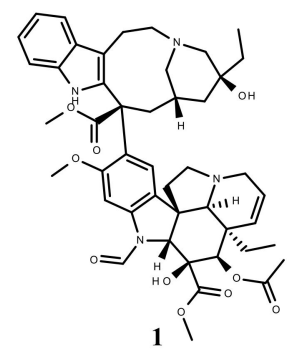

lization of the topoisomerase II cleavable complex, affecting the late S-G2 interface stage of cell cycle [20]. Crystallographic data show that etoposide, for instance, binds at the interface of DNA and each topoisomerase II chain where HB interactions are formed with both base pairs and amino acid residues (Figure 5). These patterns allowed researchers to design platinum based etoposide derivatives with higher binding capacity and increased selectivity [24].

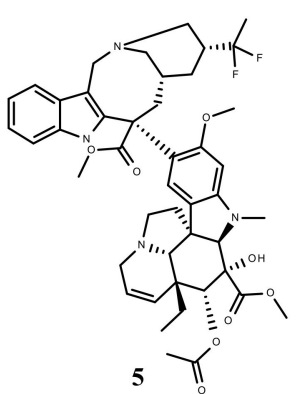

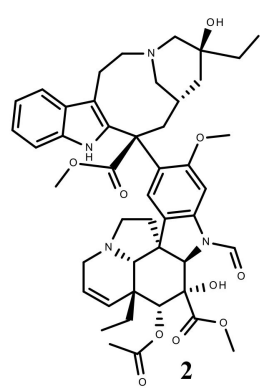

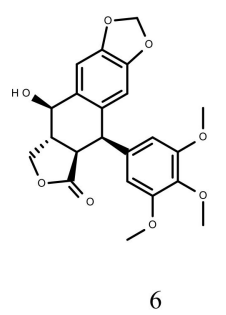

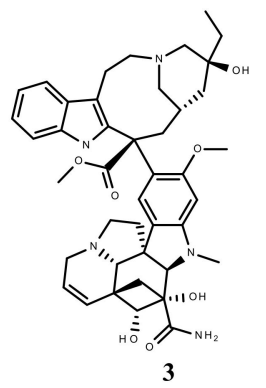
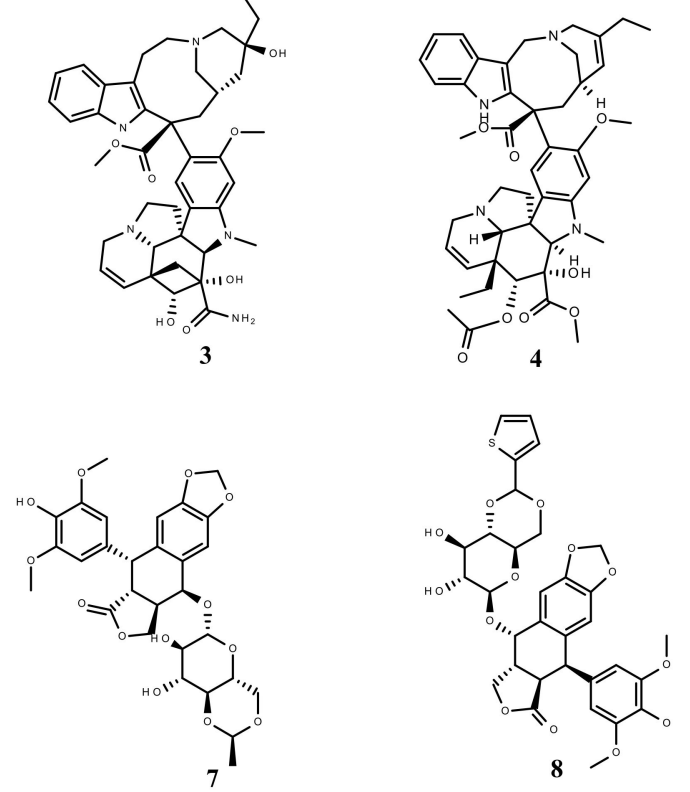

Figure 4. Chemical structures of (1) vincristine, (2) vinblastine, (3) vindesine, (4) vinorelbine, (5) vinflunine, (6) podophyllotoxin, (7) etoposide and (8) teniposide.

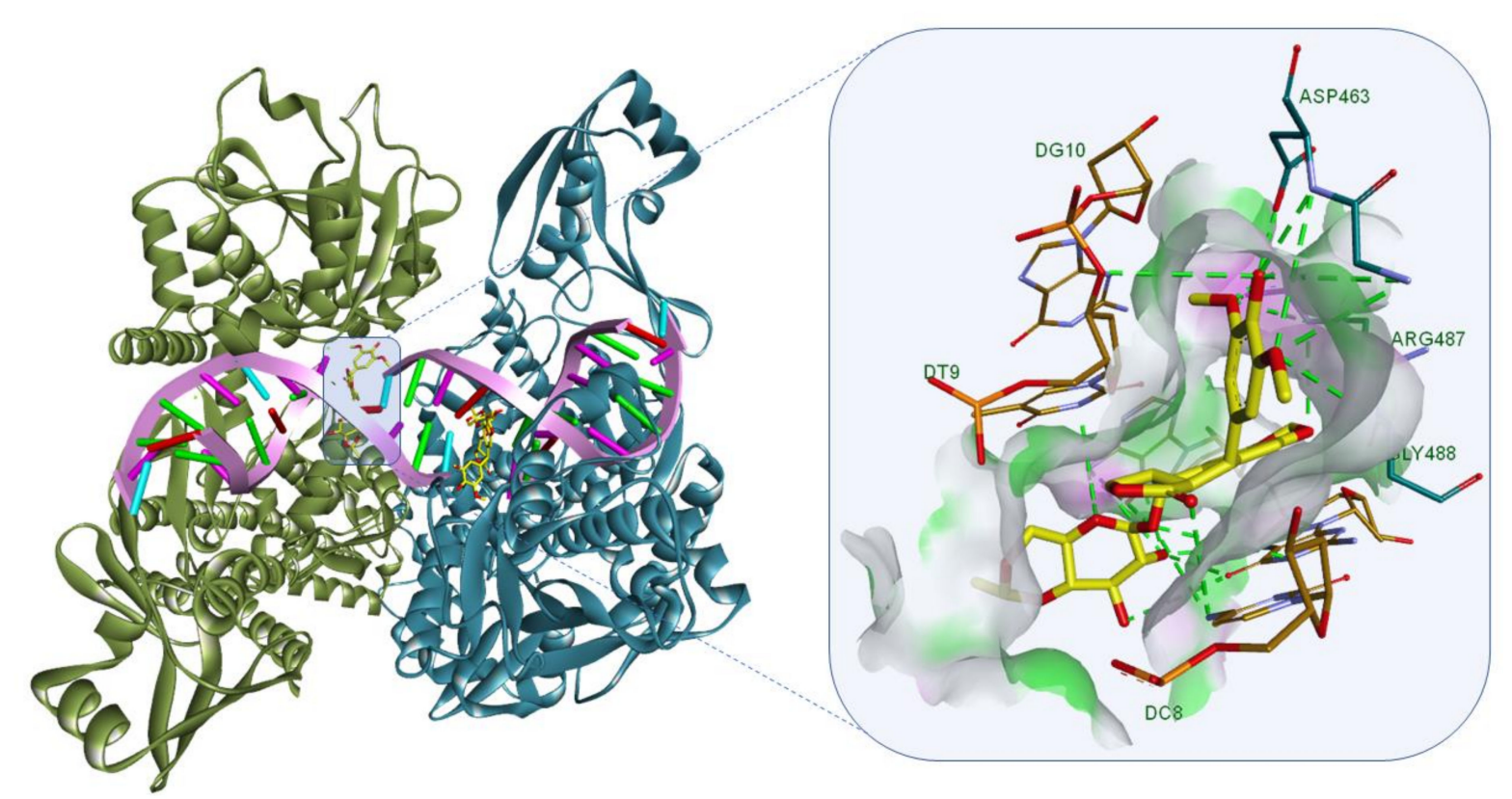

Figure 5. DNA-topoisomerase II $\alpha$-etoposide complex (PDB ID: 5GWK); HB (green dotted lines) formed by etoposide (yellow sticks) with interacting amino acids (blue sticks) and nucleotides (orange sticks). 


\subsection{Natural Compounds with Anticancer Potential}

There is a plethora of active agents under ongoing preclinical and clinical trials.

It is important to highlight the significant achievements that were made in this area of research, some secondary plant metabolites being already in clinical use while others are currently tested in clinical trials as anticancer agents [6].

One representative compound intensively studied for its antitumor effect is resveratrol (Figure 6), a phytoalexin and stilbenoid produced by several plants such as grapes, peanuts, cranberries and blueberries [7]. Significant amounts of resveratrol are present in red wine as well [8]. There were several previously described mechanisms for the antitumor activity of resveratrol, such as: (i) an anti-inflammatory effect by decreasing the expression of transcription factors (NF- $\mathrm{kB}$ ) and mediators associated with inflammation (prostaglandin E2) [7]; (ii) a proapoptotic effect by interfering with multiple signaling pathways [8], and (iii) an antioxidant effect manifested in vivo via gene regulation, partially mediated by histone/protein deacetylase sirtuin 1 or nuclear factor-erythroid 2, reduction of generation of mitochondrial superoxide, prevention of the production of superoxide from uncoupled endothelial nitric oxide synthase, and increasing the expression of various antioxidant enzymes $[25,26]$.

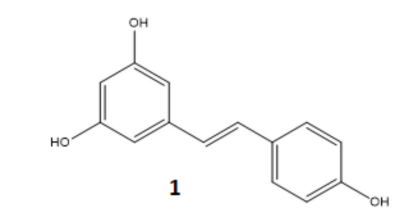<smiles>COc1cc(/C=C/C(=O)CC(=O)/C=C/c2ccc(O)c(OC)c2)ccc1O</smiles><smiles>O=C(O[C@H]1Cc2c(O)cc(O)cc2OC1c1cc(O)c(O)c(O)c1)c1cc(O)c(O)c(O)c1</smiles><smiles>O=c1c(O)c(-c2ccc(O)c(O)c2)oc2cc(O)cc(O)c12</smiles><smiles>CC1O[C@H](OC[C@H]2O[C@H](Oc3c(-c4ccc(O)c(O)c4)oc4cc(O)cc(O)c4c3=O)[C@H](O)[C@H](O)[C@@H]2O)[C@H](O)[C@@H](O)[C@@H]1O</smiles>
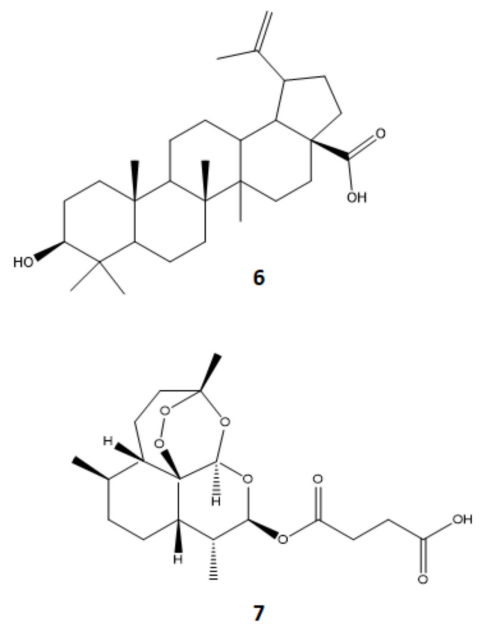

7

Figure 6. Chemical structures of (1) resveratrol, (2) curcumin, (3) EGCG, (4) quercetin, (5) rutin, (6) betulinic acid and (7) artesunate.

Regarding its biological effects, resveratrol exerted a small reduction in cell proliferation in colorectal tissue after ingestion, which is consistent with its antiproliferative activity that has been observed both in vitro (Table 1), on colorectal cells and in vivo (Table 2), on colorectal tissue in rats. Although resveratrol has shown some efficacy in cancer patients, poor bioavailability limits its use. The study conducted by Patel and colleagues investigated the pharmacological activity of resveratrol and its metabolites in twenty colorectal cancer patients who received the compound formulated as uncoated, immediate release caplets, prior to surgical resection, at either 0.5 or $1.0 \mathrm{~g}$ daily, for 8 days. They concluded that resveratrol merits further clinical evaluation in order to become an agent used in chemoprevention [27]. However, a clinical study reported that the process of micronization can enhance the absorption of resveratrol across the gastrointestinal tract, increasing its plasma levels after ingestion [28]. The efficacy, safety and pharmacokinetics of resveratrol have been extensively documented in several clinical trials (Table 3). 
Curcumin is a diarylheptanoid (Figure 6), belonging to the group of curcuminoids, which are the main components of turmeric (Curcuma longa). It has been traditionally used as an anti-inflammatory compound due to its ability to inhibit the activity of NF-KB and COX-2, while suppressing the production of prostaglandins [29]. The antitumoral activities of curcumin are mediated through inhibition of multiple signaling pathways involved in regulation of proliferation, apoptosis, survival, angiogenesis and metastasis, as presented in Tables 1 and 2. In the ongoing search for possible targets of curcumin that can relate to its antitumoral properties, a recent study reported that curcumin targets dual-specificity tyrosine-regulated kinase 2 (DYRK2), a positive regulator of the 26S proteasome [30]. Curcumin targets DYRK2 with a high specificity by binding to the ATP-binding domain (Figure 7). Researchers also showed that in a breast cancer xenograft model (Table 2), treatment with curcumin significantly reduced tumor burden in immunocompromised mice, exhibiting a similar antitumor effect as compared to clustered regularly interspaced short palindromic repeat (CRISPR)/Cas9-mediated DYRK2 [30].

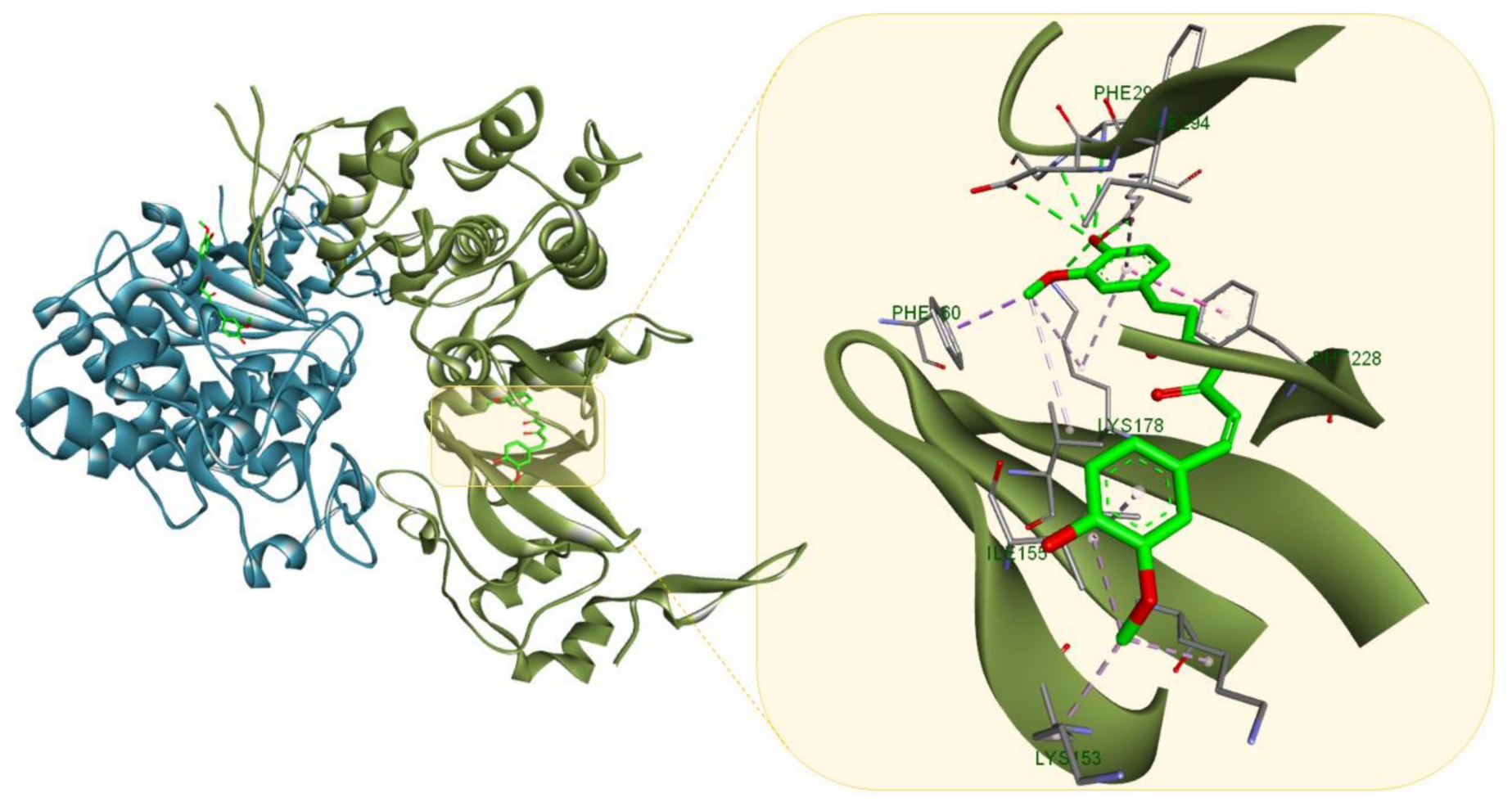

Figure 7. Curcumin (light green) in in complex with DYRK2 (PDB ID: 5ZTN); the compound interacts with the surrounding aminoacid residues through multiple HBs (green dotted lines) and several hydrophobic interactions (purple dotted lines). Protein-ligand representation was achieved using Biovia Discovery Studio 4.1 (Dassault Systems).

For instance, curcumin is one of the most extensively studied compounds to date [31]. The anticarcinogenic activity of turmeric has been shown during preclinical studies in various tumor cell lines and xenograft models, leading to phase I and II clinical trials (Table 3). According to these studies, some results are promising and demonstrated the safety of curcumin even at high doses administered over several months [32] with a maximum tolerated dose of $8000 \mathrm{mg} /$ day [31]. However, higher doses of 12,000 mg/day showed minimum toxic effects [31]. Despite its notable therapeutic potential and safety, several studies reported that oral administration of curcumin leads to a low bioavailability due to several causes-poor intestinal absorption, high rate of metabolism and rapid systemic elimination. Among all the pharmacokinetic studies in humans to date, the highest plasma concentration level was reached after the intake of $12 \mathrm{~g}$ of curcumin. Interestingly, the low bioavailability of curcumin does not seem to have an impact on 
its therapeutic effect, according to several clinical studies that have shown a remarkable efficacy despite this limitation [31].

Epigallocatechin-3-gallate (EGCG) (Figure 6) accounts for more than $50 \%$ of the total polyphenols found in green tea [33] (Camelia sinensis L.) and appears to be the most effective and best-studied constituent that actually entered the phase I and phase II clinical trials for the treatment of different types of cancer including pancreatic, bladder and lung carcinomas [32,34]. However, most of the available epidemiological evidence on tea consumption and cancer prevention in humans has not yielded conclusive results. One of the influencing factors, besides the quantity and quality of the green tea that is consumed, is the low plasma concentrations reached by EGCG [32]. The oral bioavailability of tea polyphenols in humans is low but if the administration is repeated, it leads to a $60 \%$ increase in the systemic availability of free EGCG [35]. The safety and limited side effects of EGCG were recorded during clinical trials as well [32].

Quercetin, a major representative of the flavonoid subclass of flavonols, is abundantly present in fruits and vegetables [36]. Quercetin and its glycosides were reported to be active against cancer cells by inducing DNA damage via reactive oxygen species (ROS) (e.g., hydrogen peroxide) generation [9], eliciting a high potential in oncology [36]. The anticancer effect of quercetin is dose-dependent. At low concentrations, this phytocompound has chemopreventive properties due to its antioxidant activity, while at high concentrations it acts as a pro-oxidant, manifesting a chemotherapeutic effect [36]. Several studies revealed the molecular mechanisms of the anticancer effects of quercetin, as presented in Tables 1 and 2. Quercetin is able to induce cell cycle arrest [37], apoptosis, and necrosis [38] in cancer cells, as well as autophagy, tumor angiogenesis, and metastasis inhibition [39]. In the study conducted by Sturza et al, quercetin caused a dose-dependent inhibitory effect on cellular bioenergetics of murine melanoma cells, modulating glycolytic and mitochondrial pathways for ATP production, which reveals an effective approach in eradicating cancer cells [40].

Rutin, also known as rutoside or sophorin, is a glycoside consisting of quercetin and the disaccharide rutinose. The contribution that rutin might have in cancer prevention and treatment derives from its ubiquitous pharmacological properties. It has antioxidant, anti-inflammatory, antiangiogenic, pro-apoptotic, and antiproliferative activities [41]. This biomolecule was reported to decrease adhesion and migration of human cancerous cells as well [42]. A small part of the in vitro studies that focused on rutin activity, which had continuity in vivo and subsequently reached clinical trials are presented in Tables 1-3.

Betulinic acid (Figure 6) is a lupane-type pentacyclic triterpene that extensively spread throughout the plant kingdom. The recent studies that proved the activity betulinic acid possesses against cancer cells [43,44], especially melanoma [45], led to its selection by the National Cancer Institute for addition into the Rapid Access to Intervention in Development (RAID) program. Betulinic acid exhibits significant effects both in vitro (Table 1) and in vivo (Table 2) by manifesting cytotoxicity on various cancer cell lines and suppressing the growth of tumors. There are multiple mechanisms involved in its anticancer activity, the best characterized mechanism being the induction of apoptosis by direct regulation of the mitochondrial apoptotic pathway [6,46]. However, its low water solubility is a drawback in regard of intestinal absorption and, consequently, its bioavailability. Despite its preclinical effectiveness in treating cancer, according to US National Library of Medicine - ClinicalTrials.gov there is only one registered clinical phase I and II study of betulinic acid. Unfortunately, the trial that aimed to evaluate the action of a topical $20 \%$ betulinic acid ointment against dysplastic nevi with moderate to severe dysplasia, has been suspended due to funding issues [6]. However, much more effort should be made in order to bring this compound to clinical trials as its potential of becoming an antitumoral drug has been proven via numerous preclinical experiments. Moreover, there are other anticancer molecules currently studied in clinical trials alone or in combination with other anticancer drugs [47]. 
Artemisinin, a sesquiterpene lactone derived from Artemisia annua, is commonly known for its antimalarial activity. Although the artemisinin-mediated cytotoxicity in cancer revolves around the induction of cell growth arrest on human melanoma cells [48], induction of caspase-dependent apoptosis and interference with cancer cell metabolism by reducing its uptake and suppressing ATP and lactate production [49], cell autophagy has been mentioned in a few studies as well $[50,51]$. Recently, it has been discovered that artemisinin is able to induce a form of iron-dependent, nonapoptotic cell death called ferroptosis [49]. However, not only artemisinin but also its semisynthetic derivatives (e.g. artesunate) possess significant anticancer properties on a variety of cancer types [49]. Artesunate was developed in the 1970s in attempts to treat malaria and since 2019 it is recommended as a component of the first-line treatment of severe malaria in both children and adults. Afterwards, artesunate was proved to have different pharmacological properties, such as: antimetastatic, antiproliferative, proapoptotic and antiangiogenic, becoming one of the compounds intensively researched in the field of oncology today [52].

Ginseng is the name of a group of botanicals in the genus Panax (Araliaceae), which includes species exerting a variety of pharmacological actions [53]. It is claimed to be effective in the treatment of many health problems [54] due to its richness in ginsenosides which are the major bioactive constituents of ginseng [53]. The cytotoxic effect of ginseng was reported to be via apoptosis [55] and autophagy induction [56]. Moreover, other properties such as the antiangiogenic and anti-inflammatory effects were reported [53] (Tables 1-3).

The steps from in vitro to in vivo testing and accessing clinical trials requires time and multiple resources. Based on technological advances, the time required for toxicological testing, a key step, has been reduced by methods developed by the Organization for Economic Co-operation and Development (OECD) and by the correlation of high-speed screening, biological phenotyping and integration with computer modeling in a new approach to the toxicological system [57]. In vitro studies require simpler procedures compared to in vivo and the achievement of the dose with a therapeutic effect of the dose is the basis for the implementation of clinical trials [58]. Unfortunately, the access of a molecule in the clinical trial phase is dependent at this stage mainly on the financial aspects, and most studies being stopped due to lack of funds. Additionally, favorable preclinical results usually do not translate to success in clinical trials [59] and relatively few of the actual isolated natural products are developed into clinically effective drugs [4]. 
Table 1. Relevant in vitro studies, based on natural compounds with antitumor properties, subsequently correlated with in vivo studies and clinical trials.

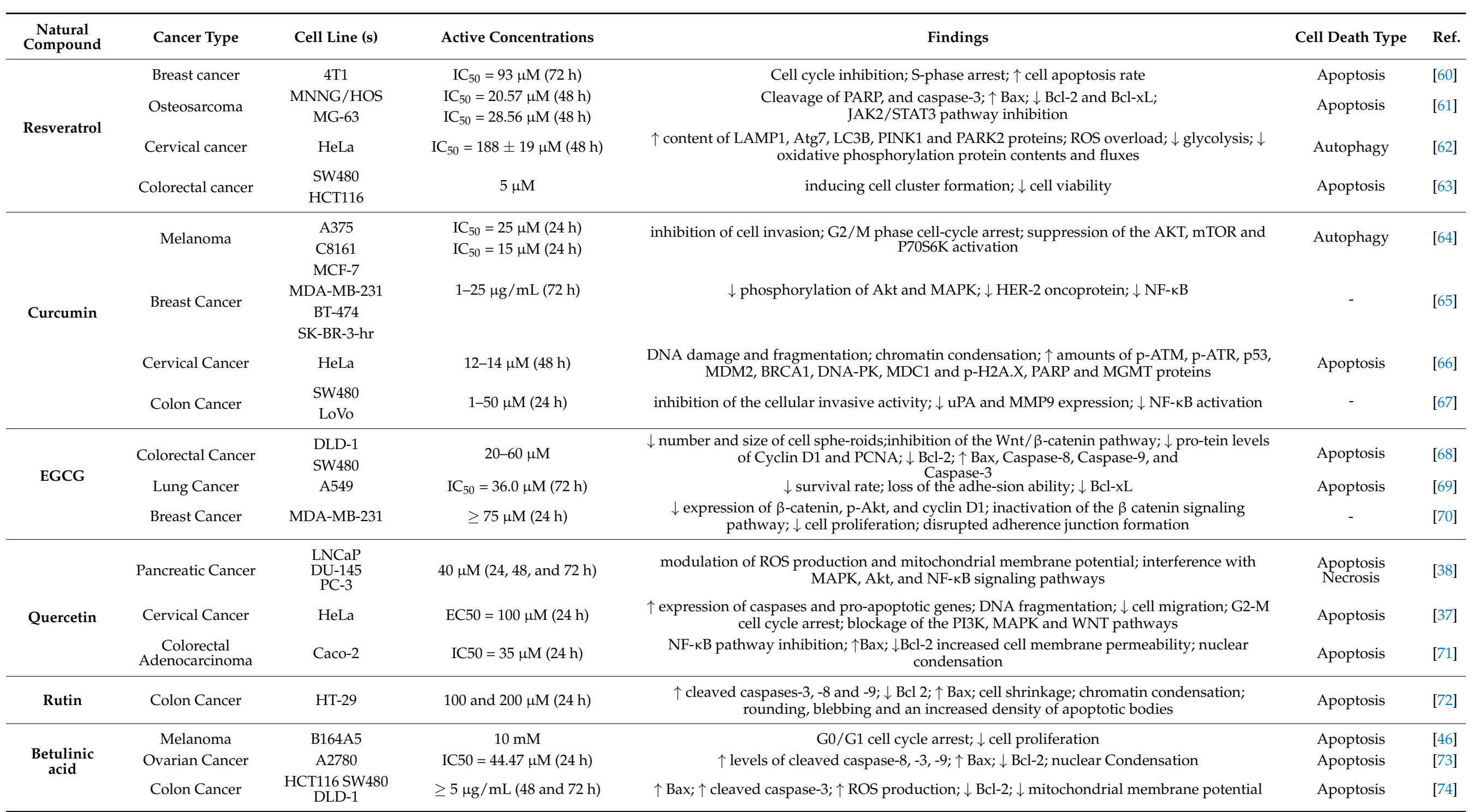


Table 1. Cont.

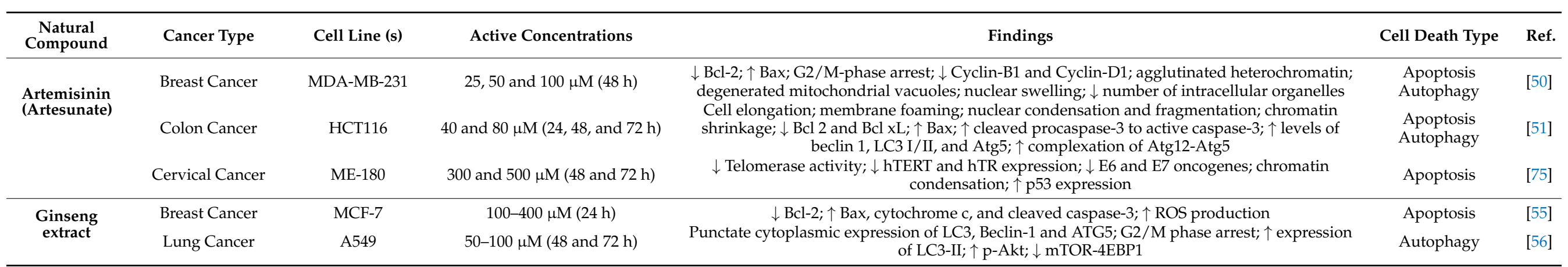

Table 2. In vivo studies achieved after the successes recorded in vitro and promulgated in clinical trials.

\begin{tabular}{|c|c|c|c|c|c|}
\hline Natural Compound & Cancer Type & Animal Model & Dose/Administration & Findings & Ref. \\
\hline \multirow{3}{*}{ Resveratrol } & Breast cancer & $\begin{array}{l}\text { MDA-MB-231 cells xenograft model in } \\
\text { female athymic mice }\end{array}$ & $\begin{array}{l}\text { intraperitoneal administration of } 25 \mathrm{mg} / \mathrm{kg} / \text { day } \\
\text { of resveratrol (ethanolic solution) for } 3 \text { weeks }\end{array}$ & $\begin{array}{l}\downarrow \text { tumor size; } \uparrow \text { apoptotic index; } \downarrow \\
\text { angiogenesis }\end{array}$ & [76] \\
\hline & Lung cancer & $\begin{array}{c}\text { A/J mice with } \\
\text { 4-[methyl(nitroso)amino]-1-(3- } \\
\text { pyridinyl)-1-butanone-induced lung } \\
\text { carcinogenesis }\end{array}$ & $\begin{array}{l}\text { intranasal administration of } \sim 60 \mathrm{mg} / \mathrm{kg} \text { three } \\
\text { times a week for } 25 \text { weeks }\end{array}$ & $\begin{array}{l}\quad \downarrow \text { tumor size }(27 \%) ; \downarrow \text { tumor } \\
\text { volume }(45 \%) \\
\text { chemopreventive properties in the } \\
\text { chemically-induced lung cancer }\end{array}$ & [77] \\
\hline & Melanoma & $\begin{array}{l}\text { B16F10 cells xenograft model in female } \\
\text { C57BL/ } 6 \text { mice }\end{array}$ & $\begin{array}{l}\text { intravenous administration of } 0.5 \mathrm{mg} / \mathrm{kg} \text { of } \\
\text { resveratrol (PBS solution) } 6 \text { times on days }-2,0 \text {, } \\
2,4,6 \text {, and } 8\end{array}$ & $\begin{array}{l}\text { inhibition of tumor growth and } \\
\text { metastasis; } \uparrow \text { NK cell activity }\end{array}$ & [78] \\
\hline \multirow{3}{*}{ Curcumin } & Breast Cancer & $\begin{array}{l}\text { HER-2-overexpressed BT-474 xenograft } \\
\text { mod-el in female athymic nude mice }\end{array}$ & $\begin{array}{l}\text { intraperitoneal administration of curcumin } \\
\text { dissolved in } 0.1 \% \text { DMSO at a dose of } 45 \mathrm{mg} / \mathrm{kg} \\
\text { twice/week for } 4 \text { consecutive weeks }\end{array}$ & $\downarrow$ tumor volume (by 76.7\%) & [65] \\
\hline & Cervical Cancer & $\begin{array}{l}\text { Human cervical cancer HeLa cells } \\
\text { xenograft model in nude mice }\end{array}$ & $\begin{array}{l}\text { intraperitoneal administration } \\
\text { of curcumin at a dosage of 50, } 100 \text { and } 200 \\
\mathrm{mg} / \mathrm{kg} \text {, once } / \text { two days for } 20 \text { days }\end{array}$ & $\begin{array}{l}\quad \downarrow \text { tumor volume and mass; } \\
\text { tumor inhibition rate percentages were } \\
1.7 \%, 31.1 \% \text { and } 39.6 \% \text { for curcumin } 50 \text {, }\end{array}$ & [79] \\
\hline & & & & $\begin{array}{l}\downarrow \text { growth of p53-positive (wt) and } \\
\text { p53-negative colon cancer HCT-116 }\end{array}$ & \\
\hline
\end{tabular}


Table 2. Cont.

\begin{tabular}{|c|c|c|c|c|c|}
\hline Natural Compound & Cancer Type & Animal Model & Dose/Administration & Findings & Ref. \\
\hline \multirow{3}{*}{ EGCG } & Colorectal Cancer & $\begin{array}{l}\text { Orthotopic colorectal cancer xenograft } \\
\text { model in BALB/c nude mice }\end{array}$ & $\begin{array}{l}\text { intragastrical administration of 5, } 10 \text { and } 20 \\
\mathrm{mg} / \mathrm{kg} \text { of EGCG once daily for } 14 \text { days }\end{array}$ & $\begin{array}{c}\downarrow \text { tumor volume; } \uparrow \text { apoptotic rates for } \\
\text { EGCG } 5,10 \text {, and } 20 \mathrm{mg} / \mathrm{kg}(38.04 \% \text {, } \\
51.87 \%, 52.27 \% \text {, and } 54.33 \%)\end{array}$ & [81] \\
\hline & Lung Cancer & $\begin{array}{l}\text { A549 cells xenograft model in BALB/c } \\
\text { nude male mice }\end{array}$ & $\begin{array}{l}0.05 \% \text { EGCG solutions in DMSO administered } \\
\text { in drinking water daily for 13-21 days }\end{array}$ & $\begin{array}{l}\downarrow \text { tumor growth; } \downarrow \text { angiogenesis and } \\
\text { CD34 positive vessels }\end{array}$ & [82] \\
\hline & Breast Cancer & $\begin{array}{l}\text { MCF-7 cells xenograft model in female } \\
\text { CB-17 severe combined } \\
\text { im-munodeficient mice }\end{array}$ & $\begin{array}{l}100 \mathrm{mg} / \mathrm{kg} \text { of EGCG dissolved in } 100 \mu \mathrm{L} \text { water } \\
\text { every } 2 \text { days by oral gavage }\end{array}$ & $\begin{array}{c}\downarrow \text { tumor growth; } \downarrow \text { expression of } \\
\text { miR-25; } \downarrow \text { Ki-67 and } \uparrow \text { pro-apoptotic } \\
\text { PARP expression }\end{array}$ & [83] \\
\hline Rutin & Colon Cancer & SW480 cells xenograft in nu/nu mice & $\begin{array}{l}\text { daily intraperitoneal administration of rutin at } \\
\text { different doses }(\leq 20 \mathrm{mg} / \mathrm{kg}) \text { for } 32 \text { days }\end{array}$ & $\begin{array}{c}\downarrow \text { tumor volume and weight; } \uparrow \text { mean } \\
\text { survival time by } 50 \text { days; } \downarrow \text { VEGF } \\
\text { serum levels (by } 55 \% \text { ) }\end{array}$ & [85] \\
\hline Betulinic acid & Colorectal cancer & HCT116 cells xenograft model in mice & $\begin{array}{l}\text { daily intraperitoneal administration of } 10 \text { and } \\
20 \mathrm{mg} / \mathrm{kg} / \text { day of betulinic acid for } 21 \text { days }\end{array}$ & $\begin{array}{c}\downarrow \text { tumor growth; } \downarrow \text { number of } \\
\text { Ki67-positive and MMP-2-positive } \\
\text { cells; } \uparrow \text { cleaved caspase-3-positive cells }\end{array}$ & [74] \\
\hline \multirow[t]{2}{*}{$\begin{array}{l}\text { Artemisinin } \\
\text { (Artesunate) }\end{array}$} & Colorectal Cancer & $\begin{array}{l}\text { CLY cells xenograft model in female } \\
\text { athymic nude mice (Balb/c nu/nu) }\end{array}$ & $\begin{array}{l}\text { intravenous administration of artesunate as } \\
\text { follows: (1) intermittent large dose treatment } \\
\text { (300 mg/kg; every } 3 \text { days, for } 7 \text { days) and } \\
\text { (2)persistent small dose treatment ( } 100 \mathrm{mg} / \mathrm{kg} \text {; } \\
\text { every day, for } 20 \text { days) }\end{array}$ & $\begin{array}{c}\text { slow growth of tumor xenografts; } \\
\downarrow \text { physiological activity of tumor } \\
\text { xenografts; delayed spontaneous } \\
\text { liver metastasis. }\end{array}$ & [87] \\
\hline & Cervical Cancer & $\begin{array}{c}\text { HeLa cells xenografts in male BALB/c } \\
\text { mice }\end{array}$ & $\begin{array}{l}\text { intraperitoneal administration of } 100 \\
\mathrm{mg} / \mathrm{kg} / \text { day artesunate for } 7 \text { days }\end{array}$ & $\begin{array}{c}\downarrow \text { microvessel density; } \uparrow \text { apoptosis; } \uparrow \\
\text { Cyclin B1 expression G2-M phase } \\
\text { arrest; } \uparrow \text { radio-sensitivity }\end{array}$ & [88] \\
\hline \multirow{2}{*}{ Ginseng } & Breast Cancer & $\begin{array}{l}\text { MCF-7 cells xenograft model in female } \\
\text { BALB/c athymic nude mice }\end{array}$ & $\begin{array}{l}\text { intravenous administration of Ginseng extract } \\
(50 \text { or } 100 \mathrm{mg} / \mathrm{kg}) \text {, once a day for } 4 \text { weeks }\end{array}$ & $\begin{array}{l}\quad \downarrow \text { tumor weight; } \uparrow \text { Bax, cleaved } \\
\text { caspase- } 3 \text {, and cleaved PARP; } \downarrow \text { Bcl-2 }\end{array}$ & [55] \\
\hline & Lung Cancer & $\begin{array}{l}\text { LLC-1 cells xenograft model in male } \\
\text { C57BL/6J mice }\end{array}$ & $\begin{array}{l}\text { Asian Ginseng extract }(0.25,0.5 \text {, and } 1 \\
\mathrm{g} / \mathrm{kg} / \text { day) daily administration as pretreatment } \\
\text { (for } 10 \text { days) and treatment (for } 20 \text { days) }\end{array}$ & $\begin{array}{c}\downarrow \text { tumor volume and mass; } \downarrow \text { cell } \\
\text { proliferative index; } \downarrow \text { P-Stat3 } \\
\text { and PCNA }\end{array}$ & [89] \\
\hline
\end{tabular}


Table 3. Relevant examples of natural compounds found in clinical trials (according to data from US National Library of Medicine - ClinicalTrials.gov).

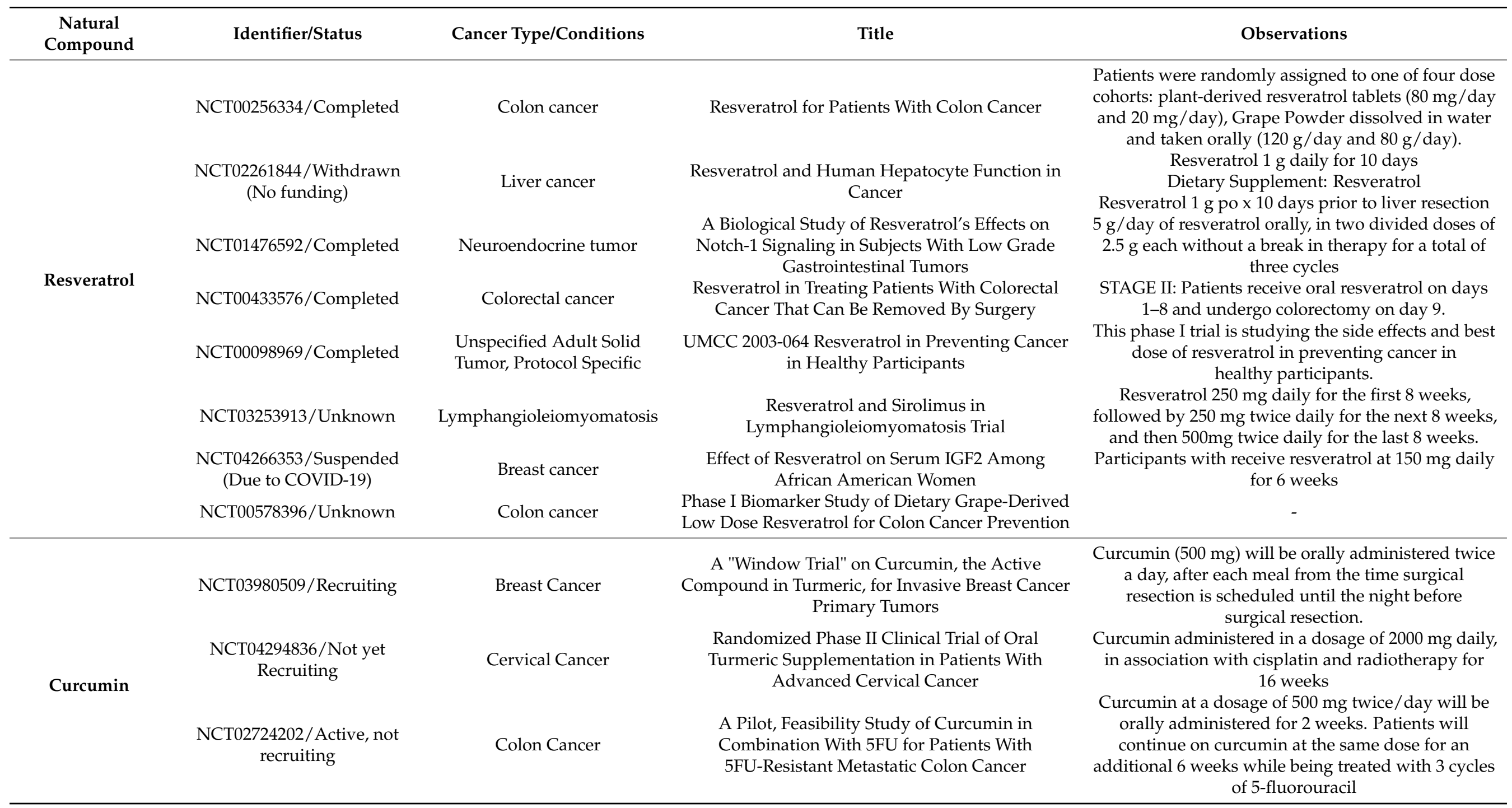


Table 3. Cont.

\begin{tabular}{|c|c|c|c|c|}
\hline $\begin{array}{l}\text { Natural } \\
\text { Compound }\end{array}$ & Identifier/Status & Cancer Type/Conditions & Title & Observations \\
\hline \multirow{3}{*}{ EGCG } & NCT02891538/Recruiting & Colorectal Cancer & $\begin{array}{l}\text { A Pilot Study to Evaluate the Chemopreventive Effects } \\
\text { of Epigallocatechin Gallate (EGCG) in Colorectal } \\
\text { Cancer (CRC) Patients With Curative Resections }\end{array}$ & $\begin{array}{l}\text { EGCG (highly purified and refined green tea } \\
\text { extract-Teavigo } \\
450 \mathrm{mg} \text { twice a day }\end{array}$ \\
\hline & NCT01317953/Available & Lung Cancer & $\begin{array}{c}\text { Phase I Study of Oral Green Tea Extract as } \\
\text { Maintenance Therapy for Extensive-stage Small Cell } \\
\text { Lung Cancer }\end{array}$ & $\begin{array}{l}\text { Increasing doses of EGCG (400, 800, 1200, } 1600 \text { and } \\
2000 \mathrm{mg} \text { ) administered daily }\end{array}$ \\
\hline & NCT00917735/Completed & Breast Cancer & $\begin{array}{l}\text { Phase II, Randomized, Double-blind, } \\
\text { Placebo-controlled, Study of the Efficacy of Green Tea } \\
\text { Extract on Biomarkers of Breast Cancer Risk in High } \\
\text { Risk Women With Differing Catechol-O-methyl } \\
\text { Transferase (COMT) Genotypes }\end{array}$ & $\begin{array}{l}\text { Oral administration of two Green tea extract } \\
\text { capsules containing } 51.7 \% \text { EGCG, twice daily after } \\
\text { breakfast and dinner for one year. }\end{array}$ \\
\hline \multirow{2}{*}{ Quercetin } & $\begin{array}{l}\text { NCT01538316/ } \\
\text { Unknown }\end{array}$ & Prostate Cancer & $\begin{array}{c}\text { Clinical Trial on the Effectiveness of the Flavonoids } \\
\text { Genistein and Quercetin in Men With Rising } \\
\text { Prostate-specific Antigen }\end{array}$ & $\begin{array}{c}500 \mathrm{mg} \text { of quercetin supplement (+ vitamin C }+ \text { folic } \\
\text { acid + vitamin B3) administered daily over a period } \\
\text { of six months, followed by genistein and placebo } \\
\text { administration. }\end{array}$ \\
\hline & NCT03476330/Recruiting & Squamous Cell Carcinoma & $\begin{array}{l}\text { Quercetin Chemoprevention for Squamous Cell } \\
\text { Carcinoma in Patients With Fanconi Anemia }\end{array}$ & $\begin{array}{l}\text { Quercetin administered orally twice daily at an } \\
\text { wheight-based adjusted dosage (maximum } \\
4000 \mathrm{mg} / \text { day). }\end{array}$ \\
\hline $\begin{array}{l}\text { Betulinic } \\
\text { acid }\end{array}$ & NCT00346502/Suspended & Dysplastic Nevus Syndrome & $\begin{array}{c}\text { Phase I/II Evaluation of Topical Application of } 20 \% \\
\text { Betulinic Acid Ointment in the Treatment of Dysplastic } \\
\text { Nevi With Moderate to Severe Dysplasia }\end{array}$ & $\begin{array}{l}\text { Daily application of the } 20 \% \text { betulinic acid ointment } \\
\text { to the dysplastic nevi site for a period of four weeks. }\end{array}$ \\
\hline \multirow{3}{*}{$\begin{array}{r}\text { Artemisimin } \\
\text { (Artesunate) }\end{array}$} & NCT00764036/Completed & Breast Cancer & $\begin{array}{l}\text { Prospective Open Uncontrolled Phase I Study of } \\
\text { Compatibility, Safety\&Pharmacokinetics of Artesunate, } \\
\text { a Semisynthetic Derivative of Artemisinin From the } \\
\text { Chinese Herb Artemisia Annua in Patients With } \\
\text { Metastatic/Locally Advanced Breast Cancer }\end{array}$ & $\begin{array}{l}\text { The administration of the drug was as follows: daily } \\
\text { single oral doses of } 100,150 \text { or } 200 \text { mg of artesunate, } \\
\text { for } 4 \text { weeks. }\end{array}$ \\
\hline & NCT03093129/Recruiting & Colorectal Cancer & $\begin{array}{l}\text { Phase II Randomised, Double Blind, Placebo } \\
\text { Controlled Trial of Neoadjuvant Artesunate in Stage } \\
\text { II/III Colorectal Cancer in Vietnamese Patients }\end{array}$ & $\begin{array}{l}\text { Daily administration of artesunate }(200 \mathrm{mg}) \text { for } \\
\qquad 14 \text { days. }\end{array}$ \\
\hline & NCT04098744/Recruiting & Cervical Neoplasia & $\begin{array}{c}\text { A Phase II Double Blind, Placebo-controlled, } \\
\text { Randomized Trial of Artesunate Vaginal Inserts for the } \\
\text { Treatment of Patients With Cervical Intraepithelial } \\
\text { Neoplasia (CIN2/3) }\end{array}$ & $\begin{array}{c}\text { Participants will receive three } 5 \text {-day cycles of } \\
\text { artesunate inserts, } 200 \mathrm{mg} \text { per day, at weeks } 0,2, \\
\text { and } 4 .\end{array}$ \\
\hline
\end{tabular}


Table 3. Cont

\begin{tabular}{|c|c|c|c|c|}
\hline $\begin{array}{l}\text { Natural } \\
\text { Compound }\end{array}$ & Identifier/Status & Cancer Type/Conditions & Title & Observations \\
\hline Rutin & NCT00003365/Terminated & Colon Cancer & $\begin{array}{l}\text { The Effect of Plant Phenolic Compounds on Human } \\
\text { Colon Epithelial Cells }\end{array}$ & $\begin{array}{l}\text { The administration of rutin was twice a day, for } \\
6-10 \text { weeks. Other phytocompounds (e.g. curcumin, } \\
\text { quercetin) were evaluated in this study as well. }\end{array}$ \\
\hline \multirow[b]{2}{*}{ Ginseng } & NCT00631852/Completed & Breast Cancer & $\begin{array}{l}\text { A Phase II Biomarker Trial of Gelatin Encapsulated } \\
\text { Extract of American Ginseng Root (LEAG) in Breast } \\
\text { Cancer }\end{array}$ & $\begin{array}{l}\text { The administration of American Ginseng Root } \\
\text { extract was organised as follows: four } 250 \mathrm{mg} \text { tablets } \\
\text { daily for 5-14 days prior to surgery. }\end{array}$ \\
\hline & NCT02603016/Completed & $\begin{array}{l}\text { Lung Neoplasm Breast } \\
\text { Carcinoma }\end{array}$ & $\begin{array}{c}\text { Phase } 1 \text { Study of Clinical Nutrition That Research Safty } \\
\text { and Efficacy in Lung Neoplasms And Breast } \\
\text { Carcinoma }\end{array}$ & $\begin{array}{l}\text { Two tablets of Ginseng were administered by mouth, } \\
\text { twice a day for } 42 \text { days. }\end{array}$ \\
\hline
\end{tabular}




\section{Natural Compounds Effective as Chemopreventive Agents}

Chemoprevention is defined as a pharmacological intervention [10] and several compounds encompassing those from natural sources, such as plants, fruits and vegetables, to synthetic molecules are able to inhibit, delay or reverse the process of tumorigenesis [4] and halt the risk of cancer recurrence [90] by blocking carcinogenic agents, increasing the capacity of the DNA repair system or acting directly against cells that carry DNA modifications by decreasing cell cycle speed or hindering events necessary for tumor spreading through metastasis [7]. It usually centers on the identification of agents that specifically impact early stages of cellular transformation [8] and addresses to people who have already developed cancer and also to those having a predisposition to any type of cancer [7]. Phytochemicals act in cancer prevention via direct and indirect strategies. The direct mechanisms include cell cycle arrest, autophagy and apoptosis, while reversing adverse epigenetic regulations, modulating miRNA expression, promoting the expression of phase II detoxification enzymes, balancing inflammation responses, aligning the circadian rhythm, and modifying gut microbiota all belong to the category of indirect chemopreventive strategies [91]. Taking into consideration the fact that the assault of free radicals causes DNA damage and alteration, phytochemicals exerting antioxidant activity could have a great contribution to cancer prevention [91,92].

In contradistinction to synthetic compounds, the naturally occurring agents have been presumed to be safer due to their presence in diet, wide availability and tolerability [10]. The identification of chemopreventive agents was possible from three main sources: (I) observations that populations presenting specific dietary habits have lower incidence of cancer development; (II) epidemiological studies or clinical tests of some drugs that show decreased number of cancers in some study populations as a secondary effect and (III) laboratory studies highlighting the inhibitory activities of some molecular entities on cancer cell cultures [7]. Phytochemicals have been found to have a wide range of cellular effects, and their chemopreventive activities can be attributed to their capacities to prevent carcinogens from reaching targeted sites, support detoxification of highly reactive molecules, enhance innate immune surveillance, improve the elimination of transformed cells or have several impacts on intrinsic DNA repair mechanisms by influencing tumor suppressors or inhibiting cellular proliferation pathways [8]. Other mechanisms involved in chemoprevention are direct inactivation of carcinogens either acting as free radical scavengers or inducing enzymes involved in scavenging, suppression of inflammatory events, induction of cell death through autophagy or apoptosis and inhibition of the epithelial-mesenchymal transition [7].

Plants are providers of endless supplies of secondary metabolites that are increasingly exploited against various cancers, among which the research on flavonoids has led to major developments in anticancer drug discoveries. The efficacy of flavonoids in chemoprevention highly depends on their pharmacokinetics and capacity of reaching to the biological site of action, as well as on their chemical structure. Moreover, flavonoids are characterized by a high availability, since they are abundantly present in our diet, such as fruits, vegetables, teas and wine, being gifted with a strong antioxidative potential, estrogenic regulatory effect, antimicrobial activity and ability to inhibit several points in cancer progression including invasion, metastasis and angiogenesis [9]. Some flavonoid compounds showing great potential in cancer prevention are apigenin, quercetin, luteolin and genistein. Apigenin is a natural phenolic compound [90], a flavone widely found in medicinal species such as Lycopodium clavatum L., as well as in some vegetables, including Petroselinum crispum L. and Apium graveolens L. Pharmacologically, it has been reported as a beneficial compound in DNA protection against UVB-induced damage via different mechanistic approaches: removal of the cyclobutane rings, inhibition of ROS generation and down-regulation of NF- $\mathrm{kB}$. Moreover, apigenin possesses anti-inflammatory and antiproliferative properties [9]. By inhibiting the COX-2 expression, inducible nitric oxide synthase (iNOS) and nitric oxide (NO) generation, apigenin suppresses the inflammatory-triggered breast carcinogenesis and proliferation [90]. This phytocompound is also responsible for 
the inhibition of the Wnt/ $\beta$-catenin signaling pathway, a key signaling cascade that participates in pivotal biological processes. Dysregulation of this pathway is frequently associated with numerous diseases including cancer [93]. The proposed mechanism for this particular activity suggests that apigenin inhibits tankyrase 2 (TNK2), an enzyme responsible for Wnt signaling pathway activation, telomere length and vesicle trafficking [93]. The study suggested that apigenin as well as other flavones target the nicotinamide binding site within TNK2 [94]. Figure 8 depicts the interactions formed by apigenin within the TNK2 binding domain. Apigenin manifests a potent activity on the endocrine function, acting as a progesterone agonist by binding to progesterone receptor and as an inhibitor of the autocrine-paracrine regulated metastatic processes, including angiogenesis, migration, invasion and adhesion through epithelial-mesenchymal transition reversal [90]. Regarding its activity on cancer cells, apigenin proved to be a pro-apoptotic compound [9].

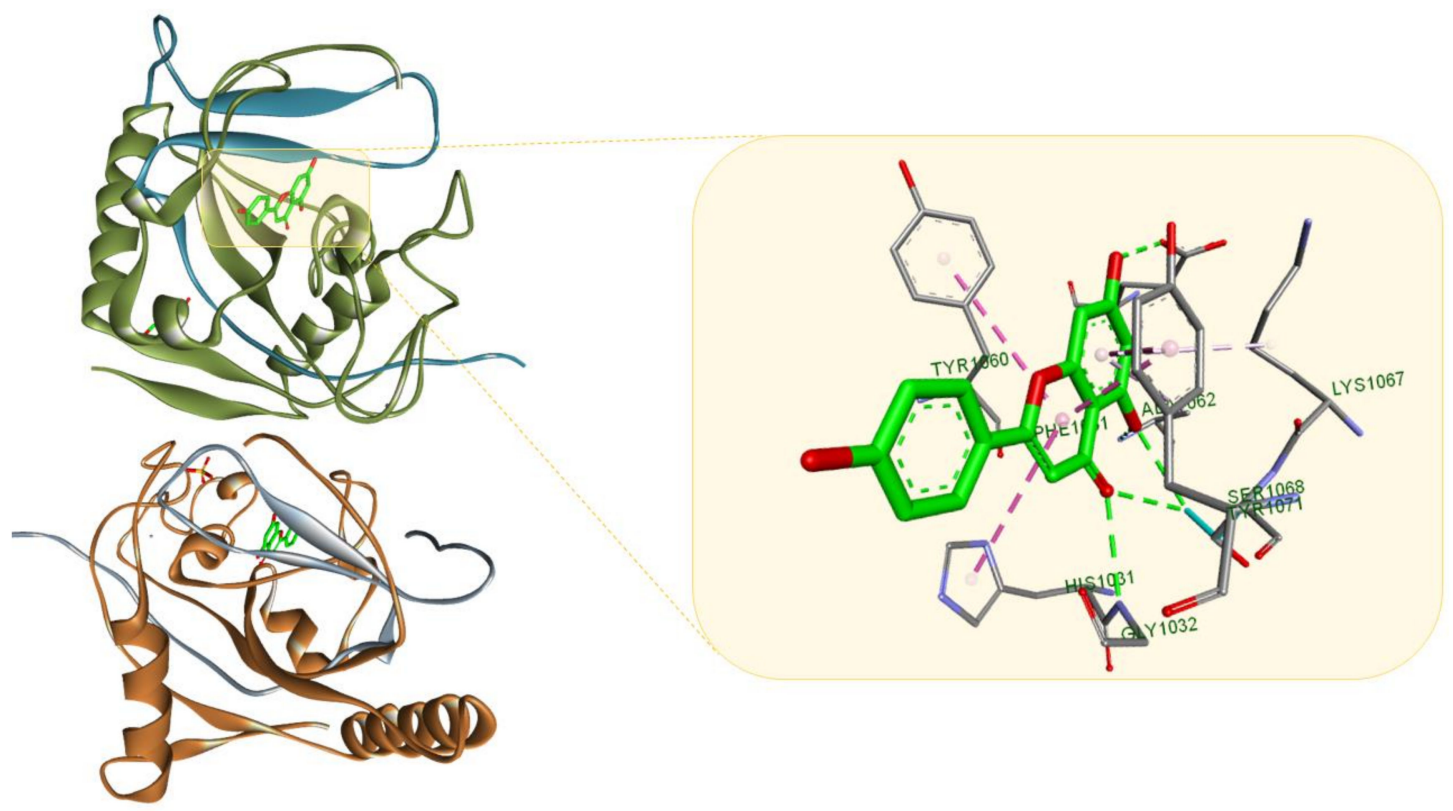

Figure 8. Apigenin (light green) in in complex with TNK2 (PDB ID: 4HKK); the flavone interacts with the surrounding amino acid residues through multiple HBs (green dotted lines) and several hydrophobic interactions (purple dotted lines). Protein-ligand representation was achieved using Biovia Discovery Studio 4.1 (Dassault Systems).

Luteolin, a flavone found in Salvia tomentosa Mill., has been shown to delay or block the development of cancer cells, protect DNA from carcinogenic stimulus and induce apoptosis even in multidrug-resistant cancer cells by ROS generation, DNA damaging, activation of Ataxia Telangiectasia and Rad3-related/Checkpoint kinase 2/p53 (ATR/Chk2/p53) signaling, depletion of antiapoptotic proteins and inhibition of NF- $\mathrm{kB}$ signaling and of p38 [9]. Furthermore, luteolin possesses a progesterone antagonist activity, which can inhibit tumor growth through various targets in antioxidant, antitoxic, antiproliferative and pro-apoptosis pathways [90].

Genistein is an isoflavone and a natural dietary polyphenol commonly found in soybean (Glycine max L.) [9,90]. It has been reported to manifest a photoprotective effect against UVB irradiation, as well as an agonistic behavior on estrogen receptors. Thus, genistein can reactivate the estrogen receptor $\alpha(E R \alpha)$ expression by remodeling chromatin structure in the ER $\alpha$ promoter and prevents tumorigenesis in $\mathrm{ER} \alpha$-negative breast cancer, which is clinically aggressive and does not respond to conventional estrogen target therapies [90]. By inducing alterations in the endocrine signaling, phenolic compounds such as apigenin, luteolin, quercetin and genistein may exert profound effects on chemoprevention and chemotherapy of hormone-dependent and independent breast cancers [90].

Curcumin might be a potential chemopreventive agent by modulating gene expression through epigenetic mechanisms [7] and some of the mechanisms involved in the effect 
on tumor cells have been highlighted in Tables 1 and 2. Several studies identified that resveratrol exerts antitumor and cancer preventive effects through regulation of diseasespecific molecular targets, affecting multiple stages of tumor initiation and proliferation [8]. This dietary polyphenol may also modulate the hormonal metabolism. A high intake of resveratrol is associated with lower risk of breast cancer, and lower levels of androgen precursors including androstenolone, could bring some benefits in the case of benign prostatic hyperplasia and cancer growth [8].

Betulin (lup-20(29)-ene-3 $\beta, 28$-diol) is a pentacyclic triterpenoid with a lupan-like structure [95]. Pentacyclic triterpenoids are active phytochemicals [96] exerting a wide spectrum of biological activities (e.g. antiviral, anti-inflammatory, anticancer) [97]. Betulin can act not only as a tumor cytotoxicity inducer [97], but also has a great potential to suppress tumor formation [96]. The role of betulin in cancer prevention and treatment results from its pro-apoptotic, antiangiogenic, and antioxidant properties [96,98], as well as its ability to alter cytomorphological features in cancer cells and to induce necrosis [95]. Betulin manifests an important scavenging effect against several radicals such as 2,2 azinobis-(3-ethylbenzothiazoline-6-sulfonic acid) (ABTS), 1-diphenyl-2-picryl hydrazyl (DPPH), NO, and superoxide anion [99] and shows immunostimulatory activity [100].

Phytochemicals are essential in the prevention of cancer occurrence and development, bringing a myriad of benefits for human health. The optimum intake of natural chemopreventive agents might be reached through diets that are rich in fruits and vegetables, as well as through the help of highly-standardized supplements containing the active compounds.

\section{Natural Compounds as Sensitizers in Drug Resistance}

Cancer is one of the most impactful diseases of the 21st century [101] and a major cause of death globally [14], each type having its own molecular fingerprint [102]. Chemotherapy is one of the main options for cancer treatment, using molecules capable of inhibiting proliferative signaling pathways, replicative immortality mechanisms and angiogenesis or inducing apoptosis of tumor cells $[103,104]$. It usually consists of either single therapy, or a combination of classical treatments, depending on several factors such as cancer type and underlying biological conditions in patients [14]. Monotherapy has been a traditional approach in treating diseases that is widely based on the pharmacological dogma of "one drug-one target". However, combined therapies proved to be much more efficient than single-drug-based treatments. The most relevant characteristic in combined therapies is the synergistic effect [14], which can be described as an increase in efficacy for a combination of components when compared with a single one [15]. Even though anticancer research and drug discovery are continuously increasing the therapeutic arsenal [102], chemotherapy fails due to adverse reactions, drug resistance and target specificity [14].

Drug resistance remains one of the most challenging aspects of chemotherapy, being a consequence of several factors depending on therapy, population of cancer cells and host environment. Vasan el al. framed the main determinants of drug resistance as follows: therapeutic pressure, tumor burden, growth and heterogeneity, physical barriers, immune system, and undruggable genome [105]. When cancer drug resistance occurs, higher doses need to be applied in order to achieve a similar tumoricidal effect as the initial dosage, which enhances the risk of severe side effects. The molecular mechanisms of chemoresistance are drug influx or efflux, DNA damage repair, cell death inhibition, drug inactivation, epithelial-to-mesenchymal transition, drug target alteration, NF- $\mathrm{kB}$ and STAT-3 activation $[15,103]$. Drug efflux, the process through which cancer cells pump chemotherapeutics out of the cells using multidrug resistance proteins, is the most important mechanism $[15,106]$. Chemosensitization by definition refers to the potentiation of the tumoricidal effect of chemotherapeutic drugs [15]. Therefore, chemosensitizers that are able to accumulate preferably within tumor site and potentialize systemic conventional therapeutic effects could represent potential candidates for fighting drug resistance [106]. According to previous studies, plant constituents can improve the effectiveness of conventional chemotherapy by increasing the residence time of chemotherapeutics in tumor cells, 
inducing cell death by up-regulation of pro-apoptotic targets, promoting DNA damage or regulating the expression of altered and unaltered drug targets. These mechanisms enhance the cytotoxic effect of anticancer drugs, promoting a synergistic effect even in the cells with acquired resistance [101,104]. Therefore, they can increase drug efficacy at lower dose levels and thus, reducing its toxicity [106]. Natural agents such as phenolic derivatives, flavonoids, alkaloids, carotenoids, terpenoids, quinones, saponins and steroids are among the potential chemosensitizers [101,103].

For instance, it has been noticed that resveratrol can sensitize resistant cells to chemotherapeutic agents via multiple mechanisms of action. To mention but a few, resveratrol was able to sensitize human cancer cell lines such as leukemia, neuroblastoma, glioblastoma and breast, prostate and pancreatic carcinomas to doxorubicin, cytarabine, actinomycin D, taxol and methotrexate by down regulating surviving expression and increasing apoptosis. It was shown as well that resveratrol enhances the chemotherapeutic potential of doxorubicin in chemoresistant B16 melanoma cells through up-regulation of the p53 tumor suppressor gene and synergistically promotes the 5-fluorouracil-mediated apoptosis [103]. Another study referring to resveratrol, highlights its potential in enhancing the effects of cisplatin on the inhibition of human non-small cell lung cancer cell proliferation via cell apoptosis induction, depolarization of mitochondrial membrane potential, release of cytochrome $\mathrm{c}$ and regulation of Bcl-2 and Bax expression [107]. Two in vitro studies revealed that the micellar co-delivery of resveratrol and quercetin or curcumin influences the doxorubicin treatment of ovarian cancer. The results, in both cases, suggest that the combination of natural compounds mitigates doxorubicin-induced cardiotoxicity through reduction in apoptosis and ROS, while providing a secondary benefit of acting as a chemosensitizer $[108,109]$.

Other studies reveal that the association between curcumin and 5-fluorouracil causes synergistic inhibition of growth and induction of potent apoptosis in resistant breast and gastric cancer cell lines in vitro, through NF- $\mathrm{kB}$ downregulation, reducing the toxicity of the drug as well $[106,110]$. Sreekanth et al. observed that the combined treatment of curcumin and paclitaxel induced a synergistic reduction in the cervical tumor incidence and volume in animals, compared with the individual treatments of paclitaxel or curcumin [111]. Suzuki and colleagues showed, both in vitro and in vivo, the ability of the soy-derived isoflavone, genistein, to potentiate the antitumor effect of 5-fluorouracil in pancreatic cancer cells. The mechanisms of action, according to authors, are induced apoptotic, as well as autophagic cell death in cancer cells [112].

\section{Efficient Platforms for the Incorporation and Delivery of Natural Compounds}

Phytochemicals have demonstrated the same validity as synthetic or semisynthetic compounds in drug discovery [102]. Regarding cancer management, they can be used in a versatile manner as chemotherapeutic, chemopreventive or chemosensitizer agents [101].

Although some natural compounds have unique antiproliferative effects, their use in clinical practice is not possible due to their toxicity or physicochemical properties, which limit their bioavailability. This is the reason why there are many of their derivatives in current clinical studies, as the modification of chemical structures increases the anticancer action and selectivity, improves the pharmacokinetic properties and decreases the side effects of natural compounds [6].

However, drawbacks such as poor solubility, limited dissolution rate, instability in extreme $\mathrm{pH}$ values, scarce absorption, high metabolization rate and fast excretion process, resulting in low bioavailability and less or no therapeutic effect, limit their use in clinical practice [101,113]. According to scientific literature reports, one approach to overcome these limitations is loading the natural compounds into different types of delivery systems such as liposomes, micelles, polymeric nanoparticles, dendrimers or inorganic nanoparticles [114]. Drug delivery refers to the use of a tool or vehicle able to carry a therapeutic agent and release it at a specific location [114] — for instance, the tumor site. These innovative carriers are able to optimize some unfavorable physicochemical features of the natural active compounds, while enhancing their pharmacological activity and 
bioavailability by enabling them to cross the cellular membranes of target cells $[113,114]$. Different forms of encapsulation have been developed throughout the last decades in order to deliver natural anticancer agents.

To name but a few examples, $\mathrm{Li}$ and collaborators [115] evaluated the preclinical antitumor effect of curcumin-loaded liposomes in colorectal cancer, compared to a standard chemotherapeutic, oxaliplatin. The curcumin-loaded liposomes were obtained using as lipids: 1,2-dimyristoyl-sn-glycero-3-phosphocholine, 1,2-dimyristoyl-sn-glycero-3phosphoethanolamine-N-[methoxy-(polyethylene gly-col)-2000], and 1,2-dimyristoyl-snglycero-3-[phospho-rac-(1-glycerol)] (sodium salt) in a 10:1 ratio (lipids : curcumin). Their study establishes that liposomal curcumin induced a dose-dependent growth inhibition and apoptosis in vitro, as well as a significant tumor growth inhibition and antiangiogenic effect in vivo. Liposomal curcumin demonstrated a greater antiproliferative effect than oxaliplatin in LoVo cells and an equivalent effect in Colo25 cells [115,116]. Zhao et al. investigated the ability of peptide and sucrose liposomes to enhance the physicochemical properties and the effect of resveratrol against breast cancer, both in vitro and in vivo. According to their results, this formulation was exceptionally efficient in inhibiting the proliferation of breast cancer cells MCF-7 $\left(\mathrm{IC}_{50}=20.89 \mu \mathrm{mol} / \mathrm{L}\right)$ and blocking tumor growth completely at a dosage of $10 \mathrm{mg} / \mathrm{kg}$ in vivo. Liposomal resveratrol was capable of inducing a greater cell apoptosis and less toxicity in mice than the compound alone and manifested a selective cytotoxic activity on cancer cells [117]. In another study, Sanna et al. developed polymeric (-)-epigallocatechin-3-gallate-encapsulated nanoparticles targeted with small molecular entities and evaluated their efficacy against prostate cancer in preclinical studies. The encapsulation led to an enhanced bioavailability and antiproliferative activity compared to the free EGCG, limiting its unwanted toxicity [118]. Lazzeroni and collaborators conducted a pilot "window-of-opportunity" presurgical trial in order to test the effect of a lecithin formulation of green tea extract in twelve women diagnosed with breast cancer. Patients received $300 \mathrm{mg}$ of extract daily for 4 weeks prior to lumpectomy or mastectomy. Firstly, their results indicated a suitable bioavailability of green tea polyphenols and EGCG in breast tumor tissue, suggesting that the formulation with lecithin is able to improve the absorption of EGCG without compromising its safety. Secondly, they noticed a positive correlation between free EGCG plasma levels and the decrease in the tumors, indicating its influence on cell proliferation in breast cancer tissue [33]. Rastegar and colleagues synthesized a novel magnetic platform based on $\beta$-cyclodextrin for the co-delivery of doxorubicin and curcumin, able to release the compounds in a $\mathrm{pH}$-dependent manner. Their drug delivery system was efficiently internalized by human breast carcinoma cells and accumulated into the tumor via external magnet guidance. Regarding the anticancer activity, a superior cytotoxicity and reduction in relative tumor volume size compared to the control group were obtained [119]. In cancer therapy, paclitaxel-based liposomes have been approved since the early 2000s, followed by the introduction of paclitaxel nanoparticles into the market [5], effectively paving the way for clinical trials of these efficient delivery platforms.

Recently, melanin — the ubiquitous biopolymer and pigment that is widely distributed in various parts of living organisms, including skin, hair and eyes [120]—came out as a promising tool for biomedical applications [121]. The exploration of melanin nanoparticles has substantially broadened new horizons in the development of novel drug delivery systems, especially due to their unique properties, which are missing in the case of conventional platforms such as liposomes, micelles, polymeric nanoparticles, and so forth [121]. The advantages include superior biocompatibility and biodegradability, intrinsic photoacoustic and photoprotective properties, radical scavenging capacity and ability to form chelates with drugs or metal ions [121,122]. Bioactive molecules can either bind to melanin via $\pi-\pi$ stacking, hydrogen bonding and van der Waals interaction, or simply be conjugated onto the surface or encapsulated within the polymer matrix of the nanoparticles [120].

For instance, Wang et al. developed doxorubicin-loaded melanin nanoparticles to enhance chemotherapy against drug-resistant thyroid cancer. The cellular uptake and 
therapeutic efficacy were significantly higher than those induced by the same amount of free doxorubicin, reaching a cell viability of $34.6 \pm 5.4 \%$, at the highest concentration of $160 \mathrm{mg} / \mathrm{L}$. Moreover, no significant cytotoxicity to normal cells was noticed, proving the biocompatibility of the nanoparticles [123]. Another research team investigated the properties and activity of polyethylene glycol (PEG)-conjugated melanin nanoparticles loaded with varied concentrations of doxorubicin. Melanin nanoparticles showed a high drug loading capacity, and the release of doxorubicin was primarily diffusion controlled. Regarding their in vitro activity, the loaded nanoparticles manifested no toxic effect on mouse fibroblasts, which indicate a good cytocompatibility, but selectively inhibited the proliferation of human breast cancer cells. Moreover, the PEGylated melanin nanoparticles, according to authors, might serve as carriers for the prolonged release of anticancer drugs [122]. Song and colleagues developed complex silver-decorated melanin-like polydopamine/mesoporous silica composites loaded with curcumin and evaluated their antibacterial and antitumor properties. Their delivery platform proved to be highly biocompatible and permitted a ROS or $\mathrm{pH}$-dependent release due to the blockage of $\pi-\pi$ and/or hydrogen bonding between the polydopamine layer and curcumin/silver. Notably, a pronounced chemotherapeutic effect on human cervical cancer cells and taxol-resistant non-small cell lung cells was observed [124]. The studies performed for the development and characterization of silver nanoparticles functionalized with betulin have highlighted cytotoxic and antiproliferative properties on murine melanoma cells in vitro (high selective toxicity and a dose-dependent pro-apoptotic effect) and an antimetastatic potential (changes of tumor cells morphology, from fusiform to a less aggressive epithelial shape) in an animal model in vivo [98]. Additionally, the conjugation of gold nanoparticles with betulin showed promising results in terms of cytotoxic and apoptotic activity on murine and human melanoma cells [125]. Betulin-based nanoemulsion proved to be a true candidate with antitumor effect in studies involving surface enhanced Raman spectroscopy (SERS) for the analysis of an animal model of induced skin cancer, validating by histological examination and chemometric methods, its beneficial effect [126].

In recent years, heat-based therapeutic strategies have gained considerable attention. Studies aimed at improving the current therapy of breast cancer with the help of liposomal nano-platforms with incorporated bioactive agent, sensitive to heat, are promising. Betulinic acid-loaded magnetoliposomes have been shown to have an enhanced antitumor activity based on impairment of mammary adenocarcinoma cells, correlated to the enucleation process and DNA fragmentation [127]. Several examples of the delivery systems developed for the discussed bioactive molecules are presented in Table 4.

Even though natural compounds present a high potential in treating several types of cancer, their pharmacokinetic characteristics hinder the clinical use. The most promising solution, in this case, seems to be the use of drug-delivery platforms which are able to improve the bioavailability and the antitumor activity of phytochemicals, while reducing their side effects. 
Table 4. Drug delivery systems for the efficient encapsulation and enhanced anticancer effect of natural compounds.

\begin{tabular}{|c|c|c|c|}
\hline $\begin{array}{l}\text { Natural } \\
\text { Compound }\end{array}$ & Drug Delivery System & Findings & Ref. \\
\hline \multirow{3}{*}{ Resveratrol } & $\begin{array}{l}\text { Peptide and Sucrose } \\
\text { Liposomes }\end{array}$ & $\begin{array}{l}\text { Prolonged drug-release in vitro; Breast cancer (MCF-7) cells growth } \\
\text { inhibition (IC50 = } 20.89 \mu \mathrm{mol} / \mathrm{L}) ; \text { Apoptosis; Tumor growth } \\
\text { inhibition in mice bearing breast cancer (Dose }=10 \mathrm{mg} / \mathrm{kg} \text { ) }\end{array}$ & [128] \\
\hline & $\begin{array}{l}\text { Sulfobutylether- } \beta \text { - } \\
\text { cyclodextrin }\end{array}$ & $\begin{array}{l}\text { Improved stability; Longer half-life; Significant cytotoxic potential } \\
\text { against non-small cell lung cancer; Suitable for pulmonary delivery }\end{array}$ & [117] \\
\hline & Gold Nanoparticles & $\begin{array}{l}\text { Optimal cellular uptake; Superior cytotoxic effects on breast, } \\
\text { pancreatic, and prostate cancers }\end{array}$ & [129] \\
\hline \multirow{3}{*}{ Curcumin } & $\begin{array}{l}\text { Silver-Decorated } \\
\text { Melanin-like } \\
\text { Polydopamine/Mesoporous } \\
\text { Silica Composites }\end{array}$ & $\begin{array}{l}\text { Improved chemotherapeutic efficiency against human cervical } \\
\text { cancer cells (HeLa) and Taxol-resistant non-small cell lung cells } \\
\text { (A549/TAX); Desirable biocompatibility; Low hemolytic activity }\end{array}$ & [124] \\
\hline & Liposomes & $\begin{array}{c}\text { Potent cytotoxic effect against human MiaPaCa pancreatic cancer } \\
\text { cells (IC50 = } 17.5 \mu \mathrm{M}) \text {; suppression of tumor growth in } \\
\text { tumor-bearing nude mice (Dose }=20 \mathrm{mg} / \mathrm{kg} \text { ); Potent } \\
\text { antiangiogenic effect }\end{array}$ & [130] \\
\hline & Cyclodextrins & $\begin{array}{l}\text { Enhanced delivery; Improved therapeutic efficacy against lung } \\
\text { cancer in vitro and in vivo }\end{array}$ & [131] \\
\hline \multirow[b]{2}{*}{ EGCG } & $\begin{array}{l}\text { Deformable Liposomal } \\
\text { Formulation }\end{array}$ & $\begin{array}{l}\text { Increased drug-release; Optimal formulation for topical delivery in } \\
\text { skin cancer prevention }\end{array}$ & [132] \\
\hline & $\begin{array}{l}\text { Folic acid and polyethylene } \\
\text { glycol (PEG)-modified } \\
\text { Nanoparticles }\end{array}$ & $\begin{array}{l}\text { Inhibition of MCF-7 cells proliferation in a dose-dependent manner; } \\
\text { Enhances targeting ability and efficacy of the drug }\end{array}$ & [133] \\
\hline \multirow{2}{*}{ Quercetin } & Lipid Nanoparticles & $\begin{array}{l}\text { Sustained release; Inhibition of the MCF-7 breast cancer cells } \\
\text { growth; Increased ROS production; Increased apoptotic and } \\
\text { necrotic indexes in MCF-7 cells }\end{array}$ & [134] \\
\hline & Polymeric Nanoparticles & $\begin{array}{l}\text { Enhanced efficacy in cancer therapy; Reduced tumor volume in } \\
\text { breast and lung-bearing mice; }\end{array}$ & [135] \\
\hline \multirow{2}{*}{ Rutin } & Proniosomal Gel & $\begin{array}{l}\text { High biocompatibility of the gel on the 3D reconstructed human } \\
\text { epidermis; Lack of irritant and phototoxic potential; Preferential } \\
\text { cytotoxic effect of the drug on melanoma cells }\left(\mathrm{IC}_{50}=8.601 \mu \mathrm{M}\right)\end{array}$ & [136] \\
\hline & $\begin{array}{l}\beta \text {-cyclodextrins and } \\
\text { hydroxypropyl- } \beta \text { - } \\
\text { cyclodextrins }\end{array}$ & $\begin{array}{l}\text { Increased antioxidant activity; Antiproliferative and pro-apoptotic } \\
\text { effect against B164A5 murine melanoma cells }\end{array}$ & [137] \\
\hline \multirow{3}{*}{$\begin{array}{l}\text { Betulinic } \\
\text { acid }\end{array}$} & Gamma-cyclodextrins & $\begin{array}{l}\text { Improved antiproliferative activity in vitro on metastatic and } \\
\text { non-metastatic B164A5 melanoma cells; G0/G1 cell-cycle arrest; } \\
\text { Reduced in vivo tumor development }\end{array}$ & [46] \\
\hline & Magnetoliposomes & $\begin{array}{l}\text { Enhanced antitumor activity when breast adenocarcinoma } \\
\text { MDA-MB-231 cells and a microtubule assembly modulatory } \\
\text { activity under hypertermic conditions; }\end{array}$ & [127] \\
\hline & Silver Nanocolloids & $\begin{array}{l}\text { Augmented anticancer effect against lung A549 and liver HepG2 } \\
\text { cancer cell lines; Cell type- and time-dependent cytotoxic effect }\end{array}$ & [138] \\
\hline \multirow{2}{*}{$\begin{array}{l}\text { Artemisinin } \\
\text { (Artesunate) }\end{array}$} & $\begin{array}{l}\text { Chitosan Magnetic } \\
\text { Nanoparticles }\end{array}$ & $\begin{array}{c}\text { Enhanced accumulation of nanoparticles in the } 4 \mathrm{~T} 1 \text { breast tumor } \\
\text { tissues of BALB/c mice model }\end{array}$ & [139] \\
\hline & $\begin{array}{l}\text { pH-Responsive Lipid } \\
\text { Nanoparticles }\end{array}$ & $\begin{array}{l}\text { Inhibition of the breast cancer cells growth; down-regulation of the } \\
\text { anti-apoptotic protein survivin, and cyclin D1; down-regulation of } \\
\text { the oncogenic proteins HER2 and HER3; Reduced expression of the } \\
\text { epidermal growth factor receptor (EGFR or HER1) }\end{array}$ & [140] \\
\hline \multirow{2}{*}{ Ginseng } & $\begin{array}{l}\text { Ginsenoside } \\
\mathrm{Rb} 1 / \text { Protopanaxadiol } \\
\text { Nanoparticles }\end{array}$ & $\begin{array}{l}\text { High encapsulation efficiency, drug loading capacity, and slow } \\
\text { release kinetics; Lack of hemolytic effect; Superior in vitro } \\
\text { anticancer activity on murine Lewis lung carcinoma }\end{array}$ & [141] \\
\hline & $\begin{array}{l}\text { Ginsenoside-based } \\
\text { multifunctional liposomal } \\
\text { delivery system }\end{array}$ & $\begin{array}{c}\text { Successful delivery of the bioactive combination drugs and } \\
\text { internalization into gastric cancer cells; Suppressed gastric cancer } \\
\text { tumor growth }\end{array}$ & [142] \\
\hline
\end{tabular}




\section{Conclusions}

Natural compounds are still considered an inexhaustible source of models in finding new active chemotherapeutic agents, while providing the basis for the discovery of new structures that can be approved as therapeutical agents for a variety of human diseases. Even though a considerable number of natural compounds prove therapeutical efficacy in preclinical studies their number decreases dramatically until they reach the clinical trial phase. The selection of the most appropriate in vitro and in vivo models that attest the effectiveness of the natural compounds and ensure their inclusion in clinical trials, remains a challenge for researchers. To overcome these liabilities, there should be proposed alternative in vitro and in silico methods that can significantly reduce the time and costs required for the in vivo studies and to concentrate the resources, especially the financial ones, for the investigation of biocompounds in clinical trials. In most cases, the effectiveness of natural compounds is limited by their low bioavailability. Thus, the researchers must focus their investigation not only on the efficacy of the compound, which is of great interest, but also on the drug delivery systems able to overcome its pharmacokinetic issues, as well as on the study of the suitable derivatives which bring several benefits regarding biological availability and efficacy.

Funding: This research received no external funding.

Conflicts of Interest: The authors declare no conflict of interest.

\section{References}

1. Veeresham, C. Natural products derived from plants as a source of drugs. J. Adv. Pharm. Technol. Res. 2012, 3, 200-201. [CrossRef] [PubMed]

2. Koparde, A.A.; Doijad, R.C.; Magdum, C.S. Natural Products in Drug Discovery. Available online: https://www.intechopen. com/books/pharmacognosy-medicinal-plants/natural-products-in-drug-discovery (accessed on 16 November 2020).

3. Yuan, H.; Ma, Q.; Ye, L.; Piao, G. The traditional medicine and modern medicine from natural products. Molecules 2016, 21, 559. [CrossRef] [PubMed]

4. Cragg, G.M.; Pezzuto, J.M. Natural products as a vital source for the discovery of cancer chemotherapeutic and chemopreventive agents. Med. Princ. Pract. 2016, 25 (Suppl 2), 41-59. [CrossRef] [PubMed]

5. Newman, D.J.; Cragg, G.M. Natural products as sources of new drugs over the nearly four decades from 01/1981 to 09/2019. J. Nat. Prod. 2020, 83, 770-803. [CrossRef] [PubMed]

6. Seca, A.M.L.; Pinto, D.C.G.A. Plant secondary metabolites as anticancer agents: Successes in clinical trials and therapeutic application. Int. J. Mol. Sci. 2018, 19, 263. [CrossRef]

7. de Melo, F.H.M.; Oliveira, J.S.; Sartorelli, V.O.B.; Montor, W.R. Cancer chemoprevention: Classic and epigenetic mechanisms inhibiting tumorigenesis. What have we learned so far? Front Oncol. 2018, 8, 644. [CrossRef]

8. Kotecha, R.; Takami, A.; Espinoza, J.L. Dietary phytochemicals and cancer chemoprevention: A review of the clinical evidence. Oncotarget 2016, 7, 52517-52529. [CrossRef] [PubMed]

9. George, V.C.; Dellaire, G.; Rupasinghe, H.P.V. Plant flavonoids in cancer chemoprevention: Role in genome stability. J. Nutr. Biochem. 2017, 45, 1-14. [CrossRef] [PubMed]

10. Gullett, N.P.; Ruhul Amin, A.R.; Bayraktar, S.; Pezzuto, J.M.; Shin, D.M.; Khuri, F.R.; Aggarwal, B.B.; Surh, Y.J.; Kucuk, O. Cancer prevention with natural compounds. Semin. Oncol. 2010, 37, 258-281. [CrossRef]

11. Thomford, N.E.; Senthebane, D.A.; Rowe, A.; Munro, D.; Seele, P.; Maroyi, A.; Dzobo, K. Natural products for drug discovery in the 21st century: Innovations for novel drug discovery. Int. J. Mol. Sci. 2018, 19, 1578. [CrossRef]

12. Atanasov, A.G.; Waltenberger, B.; Pferschy-Wenzig, E.M.; Linder, T.; Wawrosch, C.; Uhrin, P.; Temml, V.; Wang, L.; Schwaiger, S.; Heiss, E.H.; et al. Discovery and resupply of pharmacologically active plant-derived natural products: A review. Biotechnol. Adv. 2015, 33, 1582-1614. [CrossRef]

13. Meier, B.P.; Lappas, C.M. The Influence of safety, efficacy, and medical condition severity on natural versus synthetic drug preference. Med. Deci. Making 2016, 36, 1011-1019. [CrossRef]

14. Aung, T.N.; Qu, Z.; Kortschak, R.D.; Adelson, D.L. Understanding the effectiveness of natural compound mixtures in cancer through their molecular mode of action. Int. J. Mol. Sci. 2017, 18, 656. [CrossRef]

15. Lin, S.R.; Chang, C.H.; Hsu, C.F.; Tsai, M.J.; Cheng, H.; Leong, M.K.; Sung, P.J.; Chen, J.C.; Weng, C.F. Natural compounds as potential adjuvants to cancer therapy: Preclinical evidence. Br. J. Pharmacol. 2020, 177, 1409-1423. [CrossRef]

16. Calixto, J.B. The role of natural products in modern drug discovery. An. Acad. Bras. Cienc. 2019, 91. [CrossRef]

17. Mohr, K.I. History of antibiotics research. Curr. Top Microbiol. Immunol. 2016, 398, 237-272. [CrossRef]

18. McGowan, J.V.; Chung, R.; Maulik, A.; Piotrowska, I.; Walker, J.M.; Yellon, D.M. Anthracycline chemotherapy and cardiotoxicity. Cardiovasc. Drugs Ther. 2017, 31, 63-75. [CrossRef] [PubMed] 
19. Perveen, F.; Arshad, N.; Qureshi, R.; Nowsherwan, J.; Sultan, A.; Nosheen, B.; Rafique, H. Electrochemical, spectroscopic and theoretical monitoring of anthracyclines' interactions with DNA and ascorbic acid by adopting two routes: Cancer cell line studies. PLoS One 2018, 13, e0205764. [CrossRef] [PubMed]

20. Tewari, D.; Rawat, P.; Singh, P.K. Adverse drug reactions of anticancer drugs derived from natural sources. Food Chem. Toxicol. 2019, 123, 522-535. [CrossRef] [PubMed]

21. Brandt, J.P.; Gerriets, V. Bleomycin. Available online: https://www.ncbi.nlm.nih.gov/books/NBK555895/ (accessed on 2 December 2020).

22. Kellogg, E.H.; Hejab, N.M.A.; Howes, S.; Northcote, P.; Miller, J.H.; Díaz, J.F.; Downing, K.H.; Nogales, E. Insights into the distinct mechanisms of action of Taxane and non-Taxane microtubule stabilizers from Cryo-EM structures. J. Mol. Biol. 2017, 429, 633-646. [CrossRef] [PubMed]

23. Moudi, M.; Go, R.; Yien, C.Y.; Nazre, M. Vinca alkaloids. In.t J Prev. Med. 2013, 4, 1231-1235.

24. Wang, Y.R.; Chen, S.F.; Wu, C.C.; Liao, Y.W.; Lin, T.S.; Liu, K.T.; Chen, Y.S.; Li, T.K.; Chien, T.C.; Chan, N.L. Producing irreversible topoisomerase II-mediated DNA breaks by site-specific Pt(II)-methionine coordination chemistry. Nucleic Acids Res. 2017, 45, 10861-10871. [CrossRef]

25. Meng, T.; Xiao, D.; Muhammed, A.; Deng, J.; Chen, L.; He, J. Anti-inflammatory action and mechanisms of resveratrol. Molecules 2021, 26, 229. [CrossRef] [PubMed]

26. Xia, N.; Daiber, A.; Förstermann, U.; Li, H. Antioxidant effects of resveratrol in the car-diovascular system. Br. J. Pharmacol. 2017, 174, 1633-1646. [CrossRef]

27. Patel, K.R.; Brown, V.A.; Jones, D.J.; Britton, R.G.; Hemingway, D.; Miller, A.S.; West, K.P.; Booth, T.D.; Perloff, M.; Crowell, J.A.; et al. Clinical pharmacology of resveratrol and its metabolites in colorectal cancer patients. Cancer Res. 2010, 70, 7392-7399. [CrossRef]

28. Singh, A.P.; Singh, R.; Verma, S.S.; Rai, V.; Kaschula, C.H.; Maiti, P.; Gupta, S.C. Health benefits of resveratrol: Evidence from clinical studies. Med. Res. Rev. 2019, 39, 1851-1891. [CrossRef] [PubMed]

29. Desai, S.J.; Prickril, B.; Rasooly, A. Mechanisms of phytonutrient modulation of cyclooxygenase-2 (COX-2) and inflammation related to cancer. Nutr. Cancer. 2018, 70, 350-375. [CrossRef] [PubMed]

30. Banerjee, S.; Ji, C.; Mayfield, J.E.; Goel, A.; Xiao, J.; Dixon, J.E.; Guo, X. Ancient drug curcumin impedes $26 \mathrm{~S}$ proteasome activity by direct inhibition of dual-specificity tyrosine-regulated kinase 2. Proc. Natl. Acad. Sci. USA 2018, 115, 8155-8160. [CrossRef]

31. Kunnumakkara, A.B.; Harsha, C.; Banik, K.; Vikkurthi, R.; Sailo, B.L.; Bordoloi, D.; Gupta, S.C.; Aggarwal, B.B. Is curcumin bioavailability a problem in humans: Lessons from clinical trials. Expert Opin. Drug Metab. Toxicol. 2019, 15, 705-733. [CrossRef]

32. Wang, J.; Jiang, Y.F. Natural compounds as anticancer agents: Experimental evidence. World J. Exp. Med. 2012, 2, 45-57. [CrossRef] [PubMed]

33. Lazzeroni, M.; Guerrieri-Gonzaga, A.; Gandini, S.; Johansson, H.; Serrano, D.; Cazzaniga, M.; Aristarco, V.; Macis, D.; Mora, S.; Caldarella, P.; et al. A presurgical study of lecithin formulation of green tea extract in women with early breast cancer. Cancer Prev. Res. 2017, 10, 363-370. [CrossRef]

34. Musial, C.; Kuban-Jankowska, A.; Gorska-Ponikowska, M. Beneficial properties of green tea catechins. Int. J. Mol. Sci. 2020, 21, 1744. [CrossRef]

35. Chow, H.H.; Hakim, I.A.; Vining, D.R.; Crowell, J.A.; Ranger-Moore, J.; Chew, W.M.; Celaya, C.A.; Rodney, S.R.; Hara, Y.; Alberts, D.S. Effects of dosing condition on the oral bioavailability of green tea catechins after single-dose administration of Polyphenon $\mathrm{E}$ in healthy individuals. Clin. Cancer Res. 2005, 1112, 4627-4633. [CrossRef]

36. Reyes-Farias, M.; Carrasco-Pozo, C. The anti-cancer effect of quercetin: Molecular implications in cancer metabolism. Int. J. Mol. Sci. 2019, 20, 3177. [CrossRef]

37. Kedhari Sundaram, M.; Raina, R.; Afroze, N.; Bajbouj, K.; Hamad, M.; Haque, S.; Hussain, A. Quercetin modulates signaling pathways and induces apoptosis in cervical cancer cells. Biosci. Rep. 2019, 39. [CrossRef] [PubMed]

38. Ward, A.B.; Mir, H.; Kapur, N.; Gales, D.N.; Carriere, P.P.; Singh, S. Quercetin inhibits prostate cancer by attenuating cell survival and inhibiting anti-apoptotic pathways. World J. Surg. Oncol. 2018, 16, 108. [CrossRef] [PubMed]

39. Tang, S.M.; Deng, X.T.; Zhou, J.; Li, Q.P.; Ge, X.X.; Miao, L. Pharmacological basis and new insights of quercetin action in respect to its anti-cancer effects. Biomed. Pharmacother. 2020, 121, 109604. [CrossRef]

40. Sturza, A.; Pavel, I.; Ancușa, S.; Danciu, C.; Dehelean, C.; Duicu, O.; Muntean, D. Quer-cetin exerts an inhibitory effect on cellular bioenergetics of the B164A5 murine mela-noma cell line. Mol. Cell Biochem. 2018, 447, 103-109. [CrossRef]

41. Nouri, Z.; Fakhri, S.; Nouri, K.; Wallace, C.E.; Farzaei, M.H.; Bishayee, A. Targeting multiple signaling pathways in cancer: The rutin therapeutic approach. Cancers 2020, 12, 2276. [CrossRef] [PubMed]

42. Ben Sghaier, M.; Pagano, A.; Mousslim, M.; Ammari, Y.; Kovacic, H.; Luis, J. Rutin inhibits proliferation, attenuates superoxide production and decreases adhesion and migration of human cancerous cells. Biomed. Pharmacother. 2016, 84, 1972-1978. [CrossRef]

43. Guo, Y.; Zhu, H.; Weng, M.; Wang, C.; Sun, L. Chemopreventive effect of Betulinic acid via mTOR-Caspases/Bcl2/Bax apoptotic signaling in pancreatic cancer. BMC Complement Med. Ther. 2020, 20, 178. [CrossRef]

44. Kumar, P.; Bhadauria, A.S.; Singh, A.K.; Saha, S. Betulinic acid as apoptosis activator: Molecular mechanisms, mathematical modeling and chemical modifications. Life Sci. 2018, 209, 24-33. [CrossRef]

45. Gheorgheosu, D.; Duicu, O.; Dehelean, C.; Soica, C.; Muntean, D. Betulinic acid as a potent and complex antitumor phytochemical: A minireview. Anticancer Agents Med. Chem. 2014, 14, 936-945. [CrossRef] 
46. Soica, C.; Danciu, C.; Savoiu-Balint, G.; Borcan, F.; Ambrus, R.; Zupko, I.; Bojin, F.; Coricovac, D.; Ciurlea, S.; Avram, S.; et al. Betulinic acid in complex with a gamma-cyclodextrin derivative decreases proliferation and in vivo tumor development of non-metastatic and metastatic B164A5 cells. Int. J. Mol. Sci. 2014, 15, 8235-8255. [CrossRef]

47. Butler, M.S.; Robertson, A.A.; Cooper, M.A. Natural product and natural product derived drugs in clinical trials. Nat. Prod. Rep. 2014, 31, 1612-1661. [CrossRef]

48. Circioban, D.; Ledeti, A.; Vlase, G.; Moaca, A.; Ledeti, I.; Farcas, C.; Vlase, T.; Dehelean, C. Thermal degradation, kinetic analysis and evaluation of biological activity on hu-man melanoma for artemisinin. J. Therm. Anal. Calorim. 2018, 134, 741-748. [CrossRef]

49. Wong, Y.K.; Xu, C.; Kalesh, K.A.; He, Y.; Lin, Q.; Wong, W.S.F.; Shen, H.M.; Wang, J. Artemisinin as an anticancer drug: Recent advances in target profiling and mechanisms of action. Med. Res. Rev. 2017, 37, 1492-1517. [CrossRef] [PubMed]

50. Guan, X.; Guan, Y. Artemisinin induces selective and potent anticancer effects in drug resistant breast cancer cells by inducing cellular apoptosis and autophagy and G2/M cell cycle arrest. J. BUON. 2020, 25, 1330-1336.

51. Jiang, F.; Zhou, J.Y.; Zhang, D.; Liu, M.H.; Chen, Y.G. Artesunate induces apoptosis and autophagy in HCT116 colon cancer cells, and autophagy inhibition enhances the artesunate-induced apoptosis. Int. J. Mol. Med. 2018, 42, 1295-1304. [CrossRef]

52. Circioban, D.; Ledeti, I.; Suta, L.M.; Vlase, G.; Ledeti, A.; Vlase, T.; Varut, R.; Sbarcea, L.; Trandafirescu, C.; Dehelean, C. Instrumental analysis and molecular modelling of in-clusion complexes containing artesunate. J. Therm. Anal. Calorim. 2020, 142, 1951-1961. [CrossRef]

53. Dai, D.; Zhang, C.F.; Williams, S.; Yuan, C.S.; Wang, C.Z. Ginseng on cancer: Potential role in modulating inflammation-mediated angiogenesis. Am. J. Chin. Med. 2017, 45, 13-22. [CrossRef]

54. Unlu, A.; Nayir, E.; Kirca, O.; Ay, H.; Ozdogan, M. Ginseng and cancer. J. BUON. 2016, 21, 1383-1387.

55. Kim, J.; Yoo, J.M.; Kim, J.S.; Kim, S.G.; Park, J.E.; Seok, Y.M.; Son, J.H.; Kim, H.J. Anticancer effect of mountain ginseng. Evid. Based Complement Alternat. Med. 2020. [CrossRef]

56. Yoo, H.; Kim, J.M.; Jo, E.; Cho, C.; Lee, S.; Kang, H.S.; Lee, M.; Yang, P.; Jang, I. Modified Panax ginseng extract regulates autophagy by AMPK signaling in A549 human lung cancer cells. Oncol. Rep. 2017, 37, 3287-3296. [CrossRef]

57. Hartung, T. Perspectives on in vitro to in vivo extrapolations. Appl. In Vitro Toxicol. 2018, 4, 305-316. [CrossRef] [PubMed]

58. Checkley, S.; MacCallum, L.; Yates, J.; Jasper, P.; Luo, H.; Tolsma, J.; Bendtsen, C. Bridging the gap between in vitro and in vivo: Dose and schedule predictions for the ATR inhibitor AZD6738. Sci. Rep. 2015, 5, 13545. [CrossRef] [PubMed]

59. Paller, C.J.; Denmeade, S.R.; Carducci, M.A. Challenges of conducting clinical trials of natural products to combat cancer. Clin. Adv. Hematol. Oncol. 2016, 14, 447-455.

60. Wu, H.; Chen, L.; Zhu, F.; Han, X.; Sun, L.; Chen, K. The cyto-toxicity effect of resvera-trol: Cell cycle arrest and induced apoptosis of breast cancer $4 \mathrm{~T} 1$ cells. Toxins 2019, 11, 731. [CrossRef]

61. Peng, L.; Jiang, D. Resveratrol eliminates cancer stem cells of osteosarcoma by STAT3 pathway inhibition. PLoS ONE 2018, 13, e0205918.

62. Rodríguez-Enríquez, S.; Pacheco-Velázquez, S.C.; Marín-Hernández, Á.; Gallardo-Pérez, J.C.; Robledo-Cadena, D.X.; HernándezReséndiz, I.; García-García, J.D.; Belmont-Díaz, J.; López-Marure, R.; Hernández-Esquivel, L.; et al. Resveratrol inhibits cancer cell proliferation by impairing oxidative phosphorylation and inducing oxidative stress. Toxicol. Appl. Pharmacol. 2019, 370, 65-77. [CrossRef]

63. Buhrmann, C.; Shayan, P.; Goel, A.; Shakibaei, M. Resveratrol regulates colorectal cancer cell invasion by modulation of focal adhesion molecules. Nutrients 2017, 9, 1073. [CrossRef] [PubMed]

64. Zhao, G.; Han, X.; Zheng, S.; Li, Z.; Sha, Y.; Ni, J.; Sun, Z.; Qiao, S.; Song, Z. Curcumin induces autophagy, inhibits proliferation and invasion by downregulating AKT/mTOR signaling pathway in human melanoma cells. Oncol. Rep. 2016, 35, 1065-1074. [CrossRef]

65. Lai, H.W.; Chien, S.Y.; Kuo, S.J.; Tseng, L.M.; Lin, H.Y.; Chi, C.W.; Chen, D.R. The potential utility of curcumin in the treatment of HER-2-overexpressed breast cancer: An in vitro and in vivo comparison study with herceptin. Evid. Based Complement Alternat Med. 2012, 2012, 486568. [CrossRef] [PubMed]

66. Shang, H.; Chang, C.; Chou, Y.; Yeh, M.; Au, M.; Lu, H.; Chu, Y.; Chou, H.; Chou, H.; Shih, Y.; et al. Curcumin causes DNA damage and affects associated protein expression in HeLa human cervical cancer cells. Oncol. Rep. 2016, 36, 2207-2215. [CrossRef]

67. Tong, W.; Wang, Q.; Sun, D.; Suo, J. Curcumin suppresses colon cancer cell invasion via AMPK-induced inhibition of NF- $к B$, uPA activator and MMP9. Oncol Lett. 2016, 12, 4139-4146. [CrossRef]

68. Chen, Y.; Wang, X.Q.; Zhang, Q.; Zhu, J.Y.; Li, Y.; Xie, C.F.; Li, X.T.; Wu, J.S.; Geng, S.S.; Zhong, C.Y.; et al. (-)-Epigallocatechin-3Gallate inhibits colorectal cancer stem cells by suppressing Wnt/ $\beta$-catenin pathway. Nutrients 2017, 9, 572. [CrossRef] [PubMed]

69. Sonoda, J.; Ikeda, R.; Baba, Y.; Narumi, K.; Kawachi, A.; Tomishige, E.; Nishihara, K.; Takeda, Y.; Yamada, K.; Sato, K.; et al. Green tea catechin, epigallocatechin-3-gallate, attenuates the cell viability of human non-small-cell lung cancer A549 cells via reducing Bcl-xL expression. Exp. Ther. Med. 2014, 8, 59-63. [CrossRef]

70. Hong, O.; Noh, E.; Jang, H.; Lee, Y.; Lee, B.; Jung, S.; Kim, J.; Youn, H. Epigallocatechin gallate inhibits the growth of MDA-MB-231 breast cancer cells via inactivation of the $\beta$-catenin signaling pathway. Oncol. Lett. 2017, 14, 441-446. [CrossRef]

71. Zhang, X.A.; Zhang, S.; Yin, Q.; Zhang, J. Quercetin induces human colon cancer cells apoptosis by inhibiting the nuclear factor-kappa B Pathway. Pharmacogn. Mag. 2015, 11, 404-409. [CrossRef]

72. Guon, T.E.; Chung, H.S. Hyperoside and rutin of Nelumbo nucifera induce mitochondrial apoptosis through a caspase-dependent mechanism in HT-29 human colon cancer cells. Oncol. Lett. 2016, 11, 2463-2470. [CrossRef] 
73. Lee, D.; Lee, S.R.; Kang, K.S.; Ko, Y.; Pang, C.; Yamabe, N.; Kim, K.H. Betulinic acid suppresses ovarian cancer cell proliferation through induction of apoptosis. Biomolecules 2019, 9, 257. [CrossRef]

74. Zeng, A.; Hua, H.; Liu, L.; Zhao, J. Betulinic acid induces apoptosis and inhibits metastasis of human colorectal cancer cells in vitro and in vivo. Bioorg. Med. Chem. 2019, 27, 2546-2552. [CrossRef]

75. Mondal, A.; Chatterji, U. Artemisinin represses telomerase subunits and induces apoptosis in HPV-39 infected human cervical cancer cells. J. Cell Biochem. 2015, 116, 1968-1981. [CrossRef]

76. Garvin, S.; Ollinger, K.; Dabrosin, C. Resveratrol induces apoptosis and inhibits angiogenesis in human breast cancer xenografts in vivo. Cancer Lett. 2006, 231, 113-122. [CrossRef] [PubMed]

77. Monteillier, A.; Voisin, A.; Furrer, P.; Allémann, E.; Cuendet, M. Intranasal administration of resveratrol successfully prevents lung cancer in A/J mice. Sci Rep. 2018, 8, 14257. [CrossRef]

78. Lee, Y.; Shin, H.; Kim, J. In vivo anti-cancer effects of resveratrol mediated by NK cell activation. J. Innate. Immun. 2020, 1-13. [CrossRef]

79. Liu, A.; Zheng, R.; Yang, F.; Huang, L.; Zhang, L.; Zhang, J. Effects of curcumin on growth of human cervical cancer xenograft in nude mice and underlying mechanism. Food Sci. Technol. Campinas. 2017, 38, 106-111. [CrossRef]

80. Majumdar, A.P.; Banerjee, S.; Nautiyal, J.; Patel, B.B.; Patel, V.; Du, J.; Yu, Y.; Elliott, A.A.; Levi, E.; Sarkar, F.H. Curcumin synergizes with resveratrol to inhibit colon cancer. Nutr. Cancer 2009, 61, 544-553. [CrossRef] [PubMed]

81. Jin, H.; Gong, W.; Zhang, C.; Wang, S. Epigallocatechin gallate inhibits the proliferation of colorectal cancer cells by regulating Notch signaling. Onco. Targets Ther. 2013, 6, 145-153. [CrossRef] [PubMed]

82. Sakamoto, Y.; Terashita, N.; Muraguchi, T.; Fukusato, T.; Kubota, S. Effects of epigallocatechin-3-gallate (EGCG) on A549 lung cancer tumor growth and angiogenesis. Biosc.i Biotechnol. Biochem. 2013, 77, 1799-1803. [CrossRef]

83. Zan, L.; Chen, Q.; Zhang, L.; Li, X. Epigallocatechin gallate (EGCG) suppresses growth and tumorigenicity in breast cancer cells by downregulation of miR-25. Bioengineered 2019, 10, 374-382. [CrossRef]

84. Angst, E.; Park, J.L.; Moro, A.; Lu, Q.Y.; Lu, X.; Li, G.; King, J.; Chen, M.; Reber, H.A.; Go, V.L.; et al. The flavonoid quercetin inhibits pancreatic cancer growth in vitro and in vivo. Pancreas 2013, 42, 223-229. [CrossRef]

85. Alonso-Castro, A.J.; Domínguez, F.; García-Carrancá, A. Rutin exerts antitumor effects on nude mice bearing SW480 tumor. Arch Med Res. 2013, 44, 346-351. [CrossRef]

86. Cao, Y.; Feng, Y.H.; Gao, L.W.; Li, X.Y.; Jin, Q.X.; Wang, Y.Y.; Xu, Y.Y.; Jin, F.; Lu, S.L.; Wei, M.J. Artemisinin enhances the anti-tumor immune response in $4 \mathrm{~T} 1$ breast cancer cells in vitro and in vivo. Int. Immunopharmacol. 2019, 70, 110-116. [CrossRef]

87. Li, L.N.; Zhang, H.D.; Yuan, S.J.; Tian, Z.Y.; Wang, L.; Sun, Z.X. Artesunate attenuates the growth of human colorectal carcinoma and inhibits hyperactive Wnt/beta-catenin pathway. Int. J. Cancer 2007, 121, 1360-1365. [CrossRef]

88. Luo, J.; Zhu, W.; Tang, Y.; Cao, H.; Zhou, Y.; Ji, R.; Zhou, X.; Lu, Z.; Yang, H.; Zhang, S.; et al. Artemisinin derivative artesunate induces radiosensitivity in cervical cancer cells in vitro and in vivo. Radiat. Oncol. 2014, 9, 84. [CrossRef]

89. Wong, V.K.; Cheung, S.S.; Li, T.; Jiang, Z.H.; Wang, J.R.; Dong, H.; Yi, X.Q.; Zhou, H.; Liu, L. Asian ginseng extract inhibits in vitro and in vivo growth of mouse lewis lung carcinoma via modulation of ERK-p53 and NF- $\mathrm{B}$ signaling. J. Cell Biochem. 2010, 111, 899-910. [CrossRef]

90. Pan, M.H.; Chiou, Y.S.; Chen, L.H.; Ho, C.T. Breast cancer chemoprevention by dietary natural phenolic compounds: Specific epigenetic related molecular targets. Mol. Nutr. Food Res. 2015, 59, 21-35. [CrossRef]

91. Koh, Y.C.; Ho, C.T.; Pan, M.H. Recent advances in cancer chemoprevention with phytochemicals. J. Food Drug Anal. 2020, 28, 14-37. [CrossRef]

92. Kiokias, S.; Proestos, C.; Oreopoulou, V. Effect of natural food antioxidants against LDL and DNA oxidative changes. Antioxidants 2018, 7, 133. [CrossRef]

93. Lin, C.M.; Chen, H.H.; Lin, C.A.; Wu, H.C.; Sheu, J.J.; Chen, H.J. Apigenin-induced lysosomal degradation of $\beta$-catenin in Wnt/ $\beta$-catenin signaling. Sci Rep. 2017, 7, 372. [CrossRef]

94. Narwal, M.; Haikarainen, T.; Fallarero, A.; Vuorela, P.M.; Lehtiö, L. Screening and structural analysis of flavones inhibiting tankyrases. J. Med. Chem. 2013, 56, 3507-3517. [CrossRef]

95. Król, S.K.; Kiełbus, M.; Rivero-Müller, A.; Stepulak, A. Comprehensive review on betulin as a potent anticancer agent. Biomed. Res. Int. 2015, 2015, 584189. [CrossRef] [PubMed]

96. Ghante, M.H.; Jamkhande, P.G. Role of pentacyclic triterpenoids in chemoprevention and anticancer treatment: An overview on targets and underling mechanisms. J. Pharmacopuncture. 2019, 22, 55-67. [CrossRef]

97. Hordyjewska, A.; Ostapiuk, A.; Horecka, A. Betulin and betulinic acid in cancer research. J. Pre. Clin. Clin. Res. 2018, 12, 72-75. [CrossRef]

98. Danciu, C.; Pinzaru, I.; Coricovac, D.; Andrica, F.; Sizemore, I.; Dehelean, C.; Baderca, F.; Lazureanu, V.; Soica, C.; Mioc, M.; et al. Betulin silver nanoparticles qualify as efficient antimelanoma agents in in vitro and in vivo studies. Eur. J. Pharm. Biopharm. 2019, 134, 1-19. [CrossRef]

99. Chen, H.; Xiao, H.; Pang, J. Parameter optimization and potential bioactivity evaluation of a betulin extract from white birch bark. Plants 2020, 9, 392. [CrossRef]

100. Pfarr, K.; Danciu, C.; Arlt, O.; Neske, C.; Dehelean, C.; Pfeilschifter, J.M.; Radeke, H.H. Simultaneous and dose dependent melanoma cytotoxic and immune stimulatory ac-tivity of betulin. PLoS ONE 2015, 10, e0118802. [CrossRef] 
101. De Oliveira Júnior, R.G.; Christiane Adrielly, A.F.; da Silva Almeida, J.R.G.; Grougnet, R.; Thiéry, V.; Picot, L. Sensitization of tumor cells to chemotherapy by natural products: A systematic review of preclinical data and molecular mechanisms. Fitoterapia 2018, 129, 383-400. [CrossRef] [PubMed]

102. Herranz-López, M.; Losada-Echeberría, M.; Barrajón-Catalán, E. The multitarget activity of natural extracts on cancer: Synergy and xenohormesis. Medicines 2018, 6, 6. [CrossRef]

103. Gupta, S.C.; Kannappan, R.; Reuter, S.; Kim, J.H.; Aggarwal, B.B. Chemosensitization of tumors by resveratrol. Ann. N. Y. Acad. Sci. 2011, 1215, 150-160. [CrossRef] [PubMed]

104. El-Seedi, H.R.; Yosri, N.; Khalifa, S.A.M.; Guo, Z.; Musharraf, S.G.; Xiao, J.; Saeed, A.; Du, M.; Khatib, A.; Abdel-Daim, M.M.; et al. Exploring natural products-based cancer therapeutics derived from egyptian flora. J. Ethnopharmacol. 2021, 269, 113626. [CrossRef] [PubMed]

105. Vasan, N.; Baselga, J.; Hyman, D.M. A view on drug resistance in cancer. Nature 2019, 575, 299-309. [CrossRef] [PubMed]

106. Guestini, F.; McNamara, K.M.; Sasano, H. The use of chemosensitizers to enhance the response to conventional therapy in triple-negative breast cancer patients. Breast Cancer Manag. 2018, 6, 127-131. [CrossRef]

107. Ma, L.; Li, W.; Wang, R.; Nan, Y.; Wang, Q.; Liu, W.; Jin, F. Resveratrol enhanced anticancer effects of cisplatin on non-small cell lung cancer cell lines by inducing mitochondrial dysfunction and cell apoptosis. Int. J. Oncol. 2015, 47, 1460-1468. [CrossRef]

108. Carlson, L.J.; Cote, B.; Alani, A.W.; Rao, D.A. Polymeric micellar co-delivery of resveratrol and curcumin to mitigate in vitro doxorubicin-induced cardiotoxicity. J. Pharm. Sci. 2014, 103, 2315-2322. [CrossRef]

109. Cote, B.; Carlson, L.J.; Rao, D.A.; Alani, A.W.G. Combinatorial resveratrol and quercetin polymeric micelles mitigate doxorubicin induced cardiotoxicity in vitro and in vivo. J. Control. Release. 2015, 213, 128-133. [CrossRef]

110. Kang, Y.; Hu, W.; Bai, E.; Zheng, H.; Liu, Z.; Wu, J.; Jin, R.; Zhao, C.; Liang, G. Curcumin sensitizes human gastric cancer cells to 5-fluorouracil through inhibition of the NF-кB survival-signaling pathway. Onco. Targets Ther. 2016, 9, 7373-7384. [CrossRef]

111. Sreekanth, C.N.; Bava, S.V.; Sreekumar, E.; Anto, R.J. Molecular evidences for the chemosensitizing efficacy of liposomal curcumin in paclitaxel chemotherapy in mouse models of cervical cancer. Oncogene 2011, 30, 3139-3152. [CrossRef]

112. Suzuki, R.; Kang, Y.; Li, X.; Roife, D.; Zhang, R.; Fleming, J.B. Genistein potentiates the antitumor effect of 5-Fluorouracil by inducing apoptosis and autophagy in human pancreatic cancer cells. Anticancer Res. 2014, 34, 4685-4692. [PubMed]

113. Puglia, C.; Lauro, M.R.; Tirendi, G.G.; Fassari, G.E.; Carbone, C.; Bonina, F.; Puglisi, G. Modern drug delivery strategies applied to natural active compounds. Expert Opin. Drug Deliv. 2017, 14, 755-768. [CrossRef] [PubMed]

114. Obeid, M.A.; Al Qaraghuli, M.M.; Alsaadi, M.; Alzahrani, A.R.; Niwasabutra, K.; Ferro, V.A. Delivering natural products and biotherapeutics to improve drug efficacy. Ther. Deliv. 2017, 8, 947-956. [CrossRef] [PubMed]

115. Li, L.; Ahmed, B.; Mehta, K.; Kurzrock, R. Liposomal curcumin with and without oxali-platin: Effects on cell growth, apoptosis, and angiogenesis in colorectal cancer. Mol. Cancer Ther. 2007, 6, 1276-1282. [CrossRef] [PubMed]

116. Wong, K.E.; Ngai, S.C.; Chan, K.G.; Lee, L.H.; Goh, B.H.; Chuah, L.H. Curcumin nanoformulations for colorectal cancer: A review. Front Pharmacol. 2019, 10, 152. [CrossRef]

117. Zhao, Y.N.; Cao, Y.N.; Sun, J.; Liang, Z.; Wu, Q.; Cui, S.H.; Zhi, D.F.; Guo, S.T.; Zhen, Y.H.; Zhang, S.B. Anti-breast cancer activity of resveratrol encapsulated in liposomes. J. Mater. Chem. B 2020, 8, 27-37. [CrossRef]

118. Sanna, V.; Singh, C.K.; Jashari, R.; Adhami, V.M.; Chamcheu, J.C.; Rady, I.; Sechi, M.; Mukhtar, H.; Siddiqui, I.A. Targeted nanoparticles encapsulating (-)-epigallocatechin-3-gallate for prostate cancer prevention and therapy. Sci. Rep. 2017, 7, 41573. [CrossRef]

119. Rastegar, R.; Akbari Javar, H.; Khoobi, M.; Dehghan Kelishadi, P.; Hossein Yousefi, G.; Doosti, M.; Hossien Ghahremani, M.; Shariftabrizi, A.; Imanparast, F.; Gholibeglu, E.; et al. Evaluation of a novel biocompatible magnetic nanomedicine based on beta-cyclodextrin, loaded doxorubicin-curcumin for overcoming chemoresistance in breast cancer. Artif. Cells Nanomed. Biotechnol. 2018, 46, 207-216. [CrossRef]

120. Liu, H.; Yang, Y.; Liu, Y.; Pan, J.; Wang, J.; Man, F.; Zhang, W.; Liu, G. Melanin-like nanomaterials for advanced biomedical applications: A versatile platform with extraordinary promise. Adv. Sci. 2020, 7, 1903129. [CrossRef]

121. Caldas, M.; Santos, A.C.; Veiga, F.; Rebelo, R.; Reis, R.L.; Correlo, V.M. Melanin nanoparticles as a promising tool for biomedical applications-A review. Acta Biomater. 2020, 105, 26-43. [CrossRef]

122. Ozlu, B.; Kabay, G.; Bocek, I.; Yilmaz, M.; Piskin, A.K.; Shim, B.S.; Mutlu, M. Controlled release of doxorubicin from polyethylene glycol functionalized melanin nanoparticles for breast cancer therapy: Part I. Production and drug release performance of the melanin nanoparticles. Int. J. Pharm. 2019, 570, 118613. [CrossRef]

123. Wang, K.; Wang, S.; Chen, K.; Zhao, Y.; Ma, X.; Wang, L. Doxorubicin-loaded melanin particles for enhanced chemotherapy in drug-resistant anaplastic thyroid cancer cells. J. Nanomater. 2018, 2018, 2603712. [CrossRef]

124. Song, Y.; Cai, L.; Tian, Z.; Wu, Y.; Chen, J. Phytochemical curcumin-coformulated, silver-decorated melanin-like polydopamine/mesoporous silica composites with improved antibacterial and chemotherapeutic effects against drug-resistant cancer cells. ACS Omega 2020, 5, 15083-15094. [CrossRef]

125. Mioc, M.; Pavel, I.Z.; Ghiulai, R.; Coricovac, D.E.; Farcaş, C.; Mihali, C.V.; Oprean, C.; Serafim, V.; Popovici, R.A.; Dehelean, C.A.; et al. The cytotoxic effects of betulin-conjugated gold nanoparticles as stable formula-tions in normal and melanoma cells. Front Pharmacol. 2018, 9, 429. [CrossRef] [PubMed]

126. Falamas, A.; Dehelean, C.; Cinta Pinzaru, S. Monitoring of betulin nanoemulsion treatment and molecular changes in mouse skin cancer using surface enhanced Raman spectroscopy. Vib. Spectrosc. 2018, 95, 44-50. [CrossRef] 
127. Farcas, C.G.; Dehelean, C.; Pinzaru, I.A.; Mioc, M.; Socoliuc, V.; Moaca, E.A.; Avram, S.; Ghiulai, R.; Coricovac, D.; Pavel, I.; et al. Ther-mosensitive betulinic acid-loaded magnetoliposomes: A promising antitumor poten-tial for highly aggressive human breast adenocarcinoma cells under hyperthermic conditions. Int. J. Nanomed. 2020, 15, 8175-8200. [CrossRef]

128. Wang, X.; Parvathaneni, V.; Shukla, S.K.; Kanabar, D.D.; Muth, A.; Gupta, V. Cyclodextrin complexation for enhanced stability and non-invasive pulmonary delivery of resveratrol-applications in non-small cell lung cancer treatment. AAPS PharmSciTech. 2020, 21, 183. [CrossRef] [PubMed]

129. Thipe, V.C.; Panjtan Amiri, K.; Bloebaum, P.; Raphael Karikachery, A.; Khoobchandani, M.; Katti, K.K.; Jurisson, S.S.; Katti, K.V. Development of resveratrol-conjugated gold nanoparticles: Interrelationship of increased resveratrol corona on anti-tumor efficacy against breast, pancreatic and prostate cancers. Int. J. Nanomed. 2019, 14, 4413-4428. [CrossRef]

130. Ranjan, A.P.; Mukerjee, A.; Helson, L.; Gupta, R.; Vishwanatha, J.K. Efficacy of liposomal curcumin in a human pancreatic tumor xenograft model: Inhibition of tumor growth and angiogenesis. Anticancer Res. 2013, 33, 3603-3609.

131. Zhang, L.; Man, S.; Qiu, H.; Liu, Z.; Zhang, M.; Ma, L.; Gao, W. Curcumin-cyclodextrin complexes enhanced the anti-cancer effects of curcumin. Environ. Toxicol. Pharmacol. 2016, 48, 31-38. [CrossRef] [PubMed]

132. Marwah, M.; Perrie, Y.; Badhan, R.K.S.; Lowry, D. Intracellular uptake of EGCG-loaded deformable controlled release liposomes for skin cancer. J. Liposome. Res. 2020, 30, 136-149. [CrossRef]

133. Zeng, L.; Yan, J.; Luo, L.; Ma, M.; Zhu, H. Preparation and characterization of (-)-Epigallocatechin-3-gallate (EGCG)-loaded nanoparticles and their inhibitory effects on Human breast cancer MCF-7 cells. Sci Rep. 2017, 28, 45521. [CrossRef]

134. Niazvand, F.; Orazizadeh, M.; Khorsandi, L.; Abbaspour, M.; Mansouri, E.; Khodadadi, A. Effects of quercetin-loaded nanoparticles on MCF-7 human breast cancer cells. Medicina. 2019, 55, 114. [CrossRef]

135. Baksi, R.; Singh, D.P.; Borse, S.P.; Rana, R.; Sharma, V.; Nivsarkar, M. In vitro and in vivo anticancer efficacy potential of Quercetin loaded polymeric nanoparticles. Biomed. Pharmacother. 2018, 106, 1513-1526. [CrossRef]

136. Pinzaru, I.; Tanase, A.; Enatescu, V.; Coricovac, D.; Bociort, F.; Marcovici, I.; Watz, C.; Vlaia, L.; Soica, C.; Dehelean, C. Proniosomal gel for topical delivery of rutin: Preparation, physicochemical characterization and in vitro toxicological profile using $3 \mathrm{D}$ reconstructed human epidermis tissue and 2D cells. Antioxidants 2021, 10, 85. [CrossRef]

137. Danciu, C.; Bojin, F.; Pinzaru, I.; Dehelean, C.; Ambrus, R.; Popescu, A.; Paunescu, V.; Hancianu, M.; Minda, D.; Soica, C. Rutin and its cyclodextrin inclusion complexes: Physico-chemical evaluation and in vitro activity on B164A5 murine melanoma cell line. Curr. Pharm. Biotechnol. 2017, 18, 1067-1077. [CrossRef]

138. Pinzaru, I.; Sarau, C.; Coricovac, D.; Marcovici, I.; Utescu, C.; Tofan, S.; Popovici, R.A.; Manea, H.C.; Pavel, I.E.; Soica, C.; et al. Silver nanocolloids loaded with betulinic acid with enhanced antitumor potential: Physicochemical characterization and in vitro evaluation. Nanomaterials 2021, 11, 152. [CrossRef]

139. Natesan, S.; Ponnusamy, C.; Sugumaran, A.; Chelladurai, S.; Shanmugam Palaniappan, S.; Palanichamy, R. Artemisinin loaded chitosan magnetic nanoparticles for the efficient targeting to the breast cancer. Int. J. Biol. Macromol. 2017, 104, 1853-1859. [CrossRef] [PubMed]

140. Zhang, Y.J.; Gallis, B.; Taya, M.; Wang, S.; Ho, R.J.; Sasaki, T. pH-responsive artemisinin derivatives and lipid nanoparticle formulations inhibit growth of breast cancer cells in vitro and induce down-regulation of HER family members. PLoS ONE 2013, 8, e59086. [CrossRef]

141. Dai, L.; Zhu, W.; Si, C.; Lei, J. "Nano-Ginseng" for enhanced cytotoxicity against cancer cells. Int. J. Mol. Sci. 2018, 19, 627. [CrossRef]

142. Hong, C.; Wang, D.; Liang, J.; Guo, Y.; Zhu, Y.; Xia, J.; Qin, J.; Zhan, H.; Wang, J. Novel ginsenoside-based multifunctional liposomal delivery system for combination therapy of gastric cancer. Theranostics 2019, 9, 4437-4449. [CrossRef] 